\title{
What makes student entrepreneurs? - On the relevance (and irrelevance) of the university and the regional context for student start-ups
}

\author{
Heiko Bergmann \\ University of St. Gallen, Swiss Research Institute of Small Business and Entrepreneurship, \\ Dufourstrasse 40a, 9000 St. Gallen, Switzerland \\ Tel.: +41712247100 \\ Email: heiko.bergmann@unisg.ch \\ Christian Hundt \\ Ruhr-Universität Bochum, Geography Department, Urban and Regional Economics \\ Universitätsstrasse 100, 44780 Bochum, Germany \\ Email: christian.hundt@rub.de \\ Rolf Sternberg \\ Leibniz Universität Hannover, Institute of Economic and Cultural Geography \\ Schneiderberg 50, 30167 Hannover, Germany \\ Email: sternberg@wigeo.uni-hannover.de
}

\begin{abstract}
:
Student start-ups are a significant part of overall university entrepreneurship. Yet, we know little about the determinants of this type of start-ups and, specifically, the relevance of context effects. Drawing on organizational and regional context literature, we develop and test a model that aims to explain student entrepreneurship in a contextual perspective. Based on unique micro data and using multi-level techniques, we analyse nascent and new entrepreneurial activities of business and economics students at 41 European universities. Our analysis reveals that individual and contextual determinants influence students' propensity to start a business. While peoples' individual characteristics are most important, the organizational and regional contexts also play a role and have a differentiated effect, depending on the source of the venture idea and the stage of its development. Organisational characteristics, like the prevalence of fellow students who have attended entrepreneurship education, influence whether students take action to start a new firm (nascent entrepreneurship) but do not seem to support the actual establishment of a new firm. In contrast, the latter is less dependent on the university context but more strongly influenced by regional characteristics. Overall, our study contributes to our understanding of the emergence of start-ups in the organizational context of universities and has implications for initiatives and programs that aim at encouraging students to become entrepreneurs.
\end{abstract}

Keywords: University entrepreneurship; Students; Regional context; Organizational context; Multilevel analysis; Global University Entrepreneurial Spirit Students' Survey (GUESSS)

JEL-classifications: L26, M13, M14, O18

Acknowledgements: Previous versions of this paper were presented at the 2013 Babson College Entrepreneurship Research Conference, the ICSB 2014 World Conference and the 2014 Academy of Management Annual Meeting. We thank Philipp Sieger and Denis Grégoire for comments on earlier versions of this paper. The authors declare that they have no conflict of interest.

This paper has been accepted for publication in the Small Business Economics. The final publication is available at Springer via http://dx.doi.org/10.1007/s11187-016-9700-6 


\section{Introduction}

Entrepreneurship in general and, specifically, academic entrepreneurship is strongly context dependent (Bercovitz \& Feldman, 2008; Welter, 2011; Wennberg, Wiklund, \& Wright, 2011). The context an individual is exposed to provides situational opportunities and constraints and, thereby, affects the occurrence and meaning of organizational behaviour (Johns, 2006: 386). There is growing evidence that the context inside and outside the university is an important determinant of start-ups of researchers and faculty, i.e. academic entrepreneurship. Also, every university is located in a specific spatial context that may influence as to how far people perceive opportunities and whether they can be established or not (Drakopoulou Dodd \& Hynes, 2012; Sternberg, 2009; Van Looy et al., 2011). However, while there is a broad literature on academic entrepreneurship, far less research has investigated student start-ups, although they are much more frequent than start-ups by faculty and also generate substantial economic impact (Åstebro, Bazzazian, \& Braguinsky, 2012; Backes-Gellner, Demirer, \& Sternberg, 2002). By applying the knowledge their founders acquired, these start-ups contribute to knowledge spillovers from the university to the market (Wennberg et al., 2011). Companies like Facebook and Google, which were founded by students, provide additional anecdotal evidence of the importance of this type of start-ups. Yet, we know only little about when and in what circumstances students will take action to start a new business.

The literature on student entrepreneurs, including the growing literature on entrepreneurship education, has so far largely ignored contextual influences and usually looks at individual level determinants only (Martin, McNally, \& Kay, 2013; Pittaway \& Cope, 2007). This is surprising because universities have in recent years to a different degree adopted measures to increase the entrepreneurial propensity of their students, thereby creating more or less supportive contexts for starting a business (Eickelpasch \& Fritsch, 2005; Hoppe, 2015; Kuratko, 2005; Walter, Parboteeah, \& Walter, 2013). Because students typically have no or little industry experience, the university and regional context (Geissler, 2013) and their family background (Aldrich \& Cliff, 2003; Laspita, Breugst, Heblich, \& Patzelt, 2012) can be assumed to be more important for their entrepreneurial propensity than for people at a later stage of their professional career. We know of only two studies investigating student entrepreneurship in a contextual perspective (Geissler, 2013; Walter et al., 2013). Both find evidence for the relevance of context on entrepreneurial intentions, without, however, being able to analyse determinants of subsequent start-up activities. These studies also suggest that - not surprisingly - students are affected 
by other determinants than faculty members. Thus, the results from the academic entrepreneurship literature cannot easily be transferred to students.

Overall, we still need to better understand to what extent and in what way contextual characteristics influence the number and the characteristics of student start-ups. Given the increasing focus on student entrepreneurship in university support policies (Siegel \& Wright, 2015), we should know how big the 'room for manoeuvre' in this regard is. A better understanding of contextual influences will help us in designing framework conditions that foster entrepreneurial activities of students and, thus, enhance the transfer of knowledge to applications outside the 'ivory tower'. It is against this background that we aim to contribute to our understanding of the determinants of student entrepreneurship in a contextual perspective. Specifically, our research question is: To what extent and in what way do the university and the regional context influence university students' decision to take first entrepreneurial action and, subsequently, to establish a new business? We conceptually and empirically study students' entrepreneurial behaviour from a multi-level perspective, taking into account determinants on three different levels: the individual, the university, and the region. We distinguish between students who have taken first steps towards founding a business, i.e. nascent entrepreneurs, and students who are already running a new business, thereby considering two important stages of the entrepreneurial process (Carter, Gartner, \& Reynolds, 1996). We also distinguish between ventures based on business ideas from students' studies or research, i.e. from within the university, and those from other sources outside the university to investigate the degree of knowledge transfer involved.

\section{Conceptual framework}

\subsection{The growing relevance of student entrepreneurs}

The focus of our study is on student entrepreneurship, defined as venture creation activities of people who are currently studying at a university. There are at least three reasons why this type of entrepreneurship deserves our attention. First, young people and especially students generally hold a strong interest in an entrepreneurial career (Sieger, Fueglistaller, \& Zellweger, 2011). Many students are ambitious and like to try out different things while studying. It can be argued that the university is an ideal context for testing one's entrepreneurial capabilities (Houser, 2014). Secondly, research undertaken at universities serves as source of knowledge that creates new entrepreneurial opportunities which can lead 
to the formation of innovative new firms (Audretsch \& Lehmann, 2005). In recent decades, universities in a large number of countries changed their strategic behaviour and aimed at exploiting these opportunities, thus, transforming into what Etzkowitz et al. (2000) named the „entrepreneurial university“. Related to the triple-helix model of university-industry-government relations (Etzkowitz \& Leydesdorff, 1997), these paradigmatic changes of a university's role in the regional innovation system have contributed to the growing relevance of start-ups that have become an explicit, strategic goal of many universities and governments' higher education policies. While previous literature has mainly investigated start-ups of faculty and staff, i.e. academic entrepreneurship, student start-ups also contribute substantially to a knowledge transfer from the university to the market (Åstebro et al., 2012). The turnover of students ensures the role of the university as a constant source of innovation (Etzkowitz \& Leydesdorff, 2000). Thirdly, the role of the university is increasingly seen as broader than just to generate technology transfer. Audretsch (2014: 320) argues that in the entrepreneurial society the university should "provide thinking, leadership and activity to enhance entrepreneurship capital”. More and more, universities and other educational institutions try to equip their students with the necessary knowledge and skills for starting a business or acting entrepreneurially in other ways. In the past two decades there has been a dramatic increase in the number of entrepreneurship-related courses in the U.S. and in Europe (European Commission, 2012; Hoppe, 2015; Kuratko, 2005). By offering entrepreneurship courses, training, and extra-curricular support, universities aim at creating a supportive context for entrepreneurship, thereby enhancing students' motivation and capability for starting a business (Walter et al., 2013). While students typically do not start a business directly after completing their studies, they might do so at a later stage in their career (Wennberg et al., 2011). Gathering entrepreneurial experience during their studies can be assumed to facilitate subsequent start-up endeavours of students and graduates.

\subsection{The context dimension of students' business creation}

Entrepreneurial activities do not happen in isolation but take place in a social, organizational and spatial context (Autio, Kenney, Mustar, Siegel, \& Wright, 2014; Welter, 2011). For people in organizations, context has been defined as "situational opportunities and constraints that affect the occurrence and meaning of organizational behaviour" (Johns, 2006). Previous research on student entrepreneurs has largely neglected its organizational and spatial context, i.e. the characteristics of the university and the 
region where people study. As argued above, universities more or less actively support entrepreneurial activities of their staff and students, for example by offering entrepreneurship courses. While the individual effects of participating in an entrepreneurship course have been broadly investigated (Martin et al., 2013), the possible broader effects of these programs on other students are still largely unclear. Overall, empirical evidence about the university's impact on students' entrepreneurial intentions or activities is rare: Walter et al. (2013) show that organizational-level factors like the availability of entrepreneurship education and industry ties increase entrepreneurial intentions of male university students, whereas research orientation of the department has a negative effect. Geissler (2013) finds a positive effect of the perceived entrepreneurial climate at universities on students' entrepreneurial intentions. Yet, both of these studies focus on intentions rather than activities and investigate a limited number of universities only.

Besides the organizational context, the regional context is also important because start-ups have to acquire resources and find customers (Davidsson \& Honig, 2003; Mosey \& Wright, 2007) which can typically only be obtained from outside the university. The regional environment is arguably the most frequently observed spatial context in entrepreneurship research (see M. P. Feldman, 2001 and her regional event argument, see also Sternberg (2009) for overviews on regional entrepreneurship). Here, 'regional' is understood as the spatial level below the national but above the local one. Defined in that way, scholars increasingly consider it as an important part of the environment that influences an individual's decision to start a firm (Audretsch \& Lehmann, 2005; Bosma \& Schutjens, 2011; Casper, 2013; Lawton Smith \& Bagchi-Sen, 2012). The relevance of the regional economic dimension results from the empirical observation that individuals generally launch start-ups where they were born, work or live (Stam, 2009) - and that that these entrepreneurs are more successful with their new firm than those who move to another region to start their firm (Dahl \& Sorenson, 2012; Michelacci \& Silva, 2007). Regional factors include cultural, social, political, infrastructural, and financial characteristics as well as the system of education and research. Concerning entrepreneurship, agglomeration economies originating from the existence and dominance of specific industries within the relevant regions (Shane, 2003) and regional economic prosperity are particularly important (Sternberg, 2009). 


\subsection{The process dimension of students' business creation}

The venture gestation process is dependent on characteristics of the founder and the venture idea and takes place in a specific context (Davidsson, 2015).While it seems reasonable to assume that contextual influences are important for entrepreneurial activities in general and, specifically, those of students, there are also indications that their relative importance varies over the entrepreneurial process and for different types of venture ideas (Hundt \& Sternberg, 2014; Vohora, Wright, \& Lockett, 2004). Thus, we take a process perspective in our paper by considering different starting points and phases of the entrepreneurial process. First, we distinguish between different sources of the venture idea. According to a broadly accepted view, the entrepreneurial discovery process starts with the conception of a venture idea that can change and become more and more elaborate over time (Bhave, 1994; Davidsson, 2003). Beliefs and action work together to cause path dependency in the opportunity recognition and evaluation stages (Shepherd, McMullen, \& Jennings, 2007). In this evolutionary perspective, the initial venture idea can have a lasting impact on the formation of a new business because - although being evolving, usually implicit and incomplete - the idea gives direction when attempting to create new economic activities (Davidsson, 2015). For student start-ups, it is important to distinguish between venture ideas from study or research, i.e. from within the university, and ideas from outside the university because they are likely to differ concerning their innovativeness, market anchorage, and knowledge transfer. Second, we distinguish between nascent entrepreneurship and the establishment of a new business. A nascent entrepreneur can be described as a person who has taken first steps towards setting up a business which is not operating yet (Carter et al., 1996). However, not every effort to start a new business will result in a new venture (Brixy, Sternberg, \& Stüber, 2012). Only some nascent entrepreneurs will manage to form a new operating business and can then be described as new business owner-manager(s) or, in short, new entrepreneur(s). Some years after firm birth, a business is usually considered as established and not as new anymore.

Overall, we conceptually and empirically study university students' entrepreneurial behaviour from a multi-level perspective. Similar to previous conceptualizations (Djokovic \& Souitaris, 2008), we include determinants on three different levels: the micro-level, i.e. the student with his or her personal characteristics and family background, the university faculty as organizational context, and the regional 
context ${ }^{1}$. We argue that these three levels have a simultaneous - and partially interdependent - impact on a students' entrepreneurial activity. We also distinguish between two different sources of the venture idea and two stages of the gestation process. Based on this theoretical framework we now turn to the development of specific hypotheses.

\section{Hypotheses}

\subsection{The relative importance of contextual influences over the venture emergence process}

Contextual influences are likely to differ depending on the stage of the entrepreneurial process. While personal characteristics are generally considered important for the propensity to start a new business (Reynolds, 2005), there are indications that they are particularly relevant in the very early stages of the venture gestation process and that contextual characteristics become more important for managing the transition towards an operating firm. Also, different types of context (or 'external enablers' in Davidsson's words) are likely to influence ventures at different stages of this process (Davidsson, 2015). In a theoretical perspective, a person takes first action to set up a new business after he or she has evaluated the risk, uncertainty, and ambiguity of a perceived opportunity in relation to his or her own knowledge and motivation (Shepherd et al., 2007). A person's cognitive resources determine how far potential business ideas are perceived as more or less attractive. In other words, impressions of external situations or information are filtered through the lens of person-specific factors, especially peoples' knowledge and experience (Wood, McKelvie, \& Haynie, 2014). Students' human capital and entrepreneurial motivation is strongly influenced by the university environment, as an increasing number of universities try to equip their students with the necessary knowledge, skills, and motivation for starting a business by offering entrepreneurship courses and training (European Commission, 2012; Kuratko, 2005). Thus, the prevalence and attendance of such courses should have an effect on individuals' opportunity beliefs and motivation to act.

While human capital, influenced by the organizational level, is important for perceiving a favourable business idea and for taking first action, the broader, regional context is likely to become more

\footnotetext{
${ }^{1}$ We refrain from including the national level in our analysis because this would have required a different research design involving a greater number of countries. Also, a preliminary analysis suggests that the proportion of variance at the national level is only small when accounting for the individual, organizational and regional level.
} 
important for managing the transition from a nascent to a new business. Ventures face critical junctures in their development. They need to acquire specific resources and capabilities to be able to progress to the next phase (Vohora et al., 2004). These resources and contacts can usually only be obtained outside one's work or study environment. For technology-based academic entrepreneurs, entrepreneurial ventures are typically driven by a technological idea rather than the perception of a specific market demand. Nascent entrepreneurs frequently start with an invention or new technology and find it difficult to match it to a market need (Mosey \& Wright, 2007). Because of a lack of industrial and entrepreneurial experience, these entrepreneurs typically need to work together with actors from outside the university (Rasmussen, Mosey, \& Wright, 2011).

The general notion of "regional context" covers very different attributes of a region - ranging from cultural to economic or institutional ones, with the economic ones being obviously most important. This differentiation is related to the idea of different kinds of proximities that may influence the entrepreneurial behaviour of an individual and that serve as a proxy for the embeddedness of an individual within the region he/she lives in. Following Boschma's taxonomy (2005), one can distinguish between cognitive, geographical, social, organizational and institutional proximity, all of them with a clear, but mainly indirect relation to the economic context. The concept of proximities, initially developed for the purpose of explaining innovation processes, is also helpful to understand why the regional economic context may explain entrepreneurial behaviour of individuals. The deeper they are embedded (i.e. the higher their proximities are) the more likely they are to be able to progress in the entrepreneurial process.

There is some empirical support for our assumption of a growing relevance of the regional context. Not explicitly considering university students, Davidsson and Honig (2003) find human capital to be relevant in predicting entry into nascent entrepreneurship, but only weakly for managing the transition to an operating firm. Here, social capital, especially weak network ties, become more important. In the same vein, based on a multiple case-study approach of academic entrepreneurs, Mosey and Wright (2007) find that nascent entrepreneurs frequently lack the necessary networks with industry actors which hinders them in establishing an operational business. The ability to establish such networks is likely to depend on the regional context. Hundt and Sternberg (2014) provide one of the rare studies that combines a multi-level approach with the process perspective when explaining entrepreneurial activities. They show that the determinants of entrepreneurial activities vary across different stages of new firm formation. The closer the market entry, the more important become the regional and national context. 
Overall, it is reasonable to assume that - for student entrepreneurs - the organizational context facilitates nascent entrepreneurship but has only a weak effect on the establishment of a new firm, whereas in contrast, the regional context outside the university is less relevant for nascent entrepreneurship but becomes more important at later stages of the venture gestation process.

Hypothesis 1: For students, the organizational context is more important for nascent entrepreneurship than for the establishment of a new firm.

Hypothesis 2: For students, the regional context is more important for the establishment of a new firm than for nascent entrepreneurship.

After having developed two hypotheses on the general importance of different context levels, we now turn to more specific hypotheses that explain which characteristics of the organizational and regional context might explain their varying importance for nascent and new entrepreneurial activity. We focus on two determinants that we consider specifically relevant for students: peer influences, resulting from fellow students' attendance of entrepreneurship courses, and regional economic prosperity.

\subsection{Peer influences at the organizational level}

According to social learning theory, people learn through direct experience or by observing the behavior of others (Bandura, 1971). This also applies to the organizational context, where people observe others and think about the consequences of their own behavior. There is growing empirical evidence for the relevance of such peer influences on entrepreneurial behavior or intentions in different types of contexts: academics at universities (Bercovitz \& Feldman, 2008; Stuart \& Ding, 2006), workplace peers in general (Nanda \& Sørensen, 2010), and even school pupils (Falck, Heblich, \& Luedemann, 2012).

In the university context only few people start new businesses while other entrepreneurshiprelated activities of peers are more widespread and are likely to have an impact on people's entrepreneurial propensity. As discussed above, an increasing number of universities offer entrepreneurship courses and training. We argue that these programs do not only influence participants but have an additional, broader effect on other fellow students because of the following two reasons: First, referring to organizational climate theory, members of an organization perceive and interpret organizational policies, practices, and procedures in psychologically meaningful terms (Rentsch, 1990). A high number of 
students who have taken an entrepreneurship course provides a signal to students that the university fosters and encourages learning about entrepreneurship and that becoming entrepreneurial is a desired role behavior. Geissler et al. (2010) find some empirical support for this conjecture: For students, the perception of the existence and quality of entrepreneurship qualification programs is the most important factor influencing the evaluation of the entrepreneurial climate. Secondly, students interact with each other, especially if they are studying the same subject. If socially comparable individuals engage in entrepreneurial activities or entrepreneurial education, people might also consider this option for themselves (Bercovitz \& Feldman, 2008). Such peers might provide people with relevant information but might also provide motivation or assistance to try to start a venture. Thus, it can be argued that entrepreneurship courses foster the establishment of localized social capital for entrepreneurs (Kwon, Heflin, \& Ruef, 2013). Overall, we assume that the prevalence of fellow students who have attended entrepreneurship education increases people's own propensity to carry out first entrepreneurial activity, even when controlling for individual-level characteristics like entrepreneurship learning from own course participation.

While this peer effect is likely to hold for nascent entrepreneurship, we see less reason to assume that it also affects the further progress in the venture creation process, i.e. new entrepreneurship. Students have typically only little industry experience and are, therefore, unlikely to be able to provide contacts to resource providers or customers outside the university, which might contribute to the establishment of a new business. The likelihood of forming an operating business should more strongly be influenced by regional demand factors, as argued in the next section.

Hypothesis 3: Controlling for individual characteristics, the prevalence of fellow students who have attended entrepreneurship education has a positive effect on nascent entrepreneurship of students.

\subsection{Regional economic prosperity as part of the regional context in general}

Among the most important economic characteristics of regions are agglomeration effects, i.e. localisation and urbanisation economies (see Beaudry \& Schiffauerova, 2009, for an overview). Both types of agglomeration economies generate manifold inter-industrial linkages and diversified labour markets of a relevant size and are positively correlated with regional economic prosperity, typically measured in 
terms of GDP/capita (Sternberg, 2009). There is clear empirical evidence that such agglomeration economies favour the probability of entrepreneurial activity in a region, either as urbanization effects (Rosenthal \& Strange, 2004) or as localisation effects (Bosma \& Sternberg, 2014).

Regional entrepreneurship literature largely agrees that the regional context in general (see also section 3.1) and regional economic prosperity in particular have a positive impact on the probability of the local population to start a new business. A number of studies show a statistically significant impact of economic prosperity (measured in terms of regional GDP/capita) on indicators of entrepreneurial activity (see, e.g., Audretsch \& Keilbach, 2004; Sternberg \& Wagner, 2005; Stuetzer, Obschonka, Brixy, Sternberg, \& Cantner, 2014 for German regions; Reynolds, Carter, Gartner, \& Greene, 2004; Reynolds, Miller, \& Maki, 1995 for U.S. labor market areas; Andersson \& Koster, 2011 for Swedish regions, and Acs, Bosma, \& Sternberg, 2011, for so-called 'world cities' in various countries) ${ }^{2}$. Recent studies on academic entrepreneurship have also found regional economic prosperity to be positively related to the number and quality of university spin-offs (Audretsch \& Lehmann, 2005; Casper, 2013). A high regional GDP/capita may pull individuals into entrepreneurship because it signals a high demand for products and services (Audretsch \& Fritsch, 1994). High GDP/capita leads to high regional purchasing power which makes entrepreneurial activity more lucrative, and, consequently, may increase the probability that individuals perceive an opportunity for starting a business (Bosma \& Schutjens, 2011). Thus, the effects of regional attributes like GDP/capita on entrepreneurial activities are indirect, via the perception of entrepreneurial opportunities, rather than direct (Stuetzer et al., 2014).

However, while previous research found a relationship between economic prosperity and both, nascent and new entrepreneurial activity, these studies mainly investigated entrepreneurial activities of the general population in a region. We argue that for students, regional economic prosperity should be more important for the establishment of a new firm than for nascent entrepreneurship. As argued above, the university environment sends important entrepreneurial signals in the early stage of the entrepreneurial process (see also hypotheses 1 and 3 ) and might motivate students to try to start a new business

\footnotetext{
${ }^{2}$ To the best of our knowledge there is only one study that discovers a statistically significant negative impact of regional GDP/capita on nascent entrepreneurial activities (Bergmann \& Sternberg, 2007), the reasons of which were presumably related to the very specific and unusual situation after the burst of the dotcom bubble 20002002 .
} 
without having a clear idea of demand for this new product or service. Yet, this demand becomes critical for managing the transition from a nascent to an operating firm. As it is well-known that many new firms get their first customers in the region where the founders live (i.e. the location of the start-up) or from the private networks of the founders, the regional context and especially regional economic prosperity should become critical for establishing a new firm. Also, because starting business is a process and takes some time, people who are more advanced in the entrepreneurial process should also be better embedded in their study region and, thus, better know actual or potential customers in that very region (Boschma, 2005), leading to a stronger demand-side effect.

Hypothesis 4: Controlling for individual characteristics, a regional economic prosperity has a positive effect on the establishment of new firms of students.

\section{$4 \quad$ Data and methods}

\subsection{Data}

In the empirical part of our paper, we use micro data of the 2011 Global University Entrepreneurial Spirit Students' Survey (GUESSS). GUESSS is an international research project that investigates and compares entrepreneurial attitudes and activities of students in 26 countries in the world. Similar to other research in this area (Abreu \& Grinevich, 2013), data are gathered by means of an online survey which can be considered a suitable method to reach students at different universities in different countries (Dillman et al., 2009, p.44). In GUESSS, there are national teams in the participating countries which are responsible for enlisting universities for this study. The link to the online-survey is sent out by the participating universities, ideally to all of its students. In spring 2011, more than one million students were invited to participate and 93,265 students completed the questionnaire (Sieger et al., 2011). Previous research based on GUESSS data has e.g. looked at career choice intentions of students (Laspita et al., 2012; Zellweger, Sieger, \& Halter, 2011) or the formation of opportunity beliefs (Bergmann, 2015).

We do not use the full GUESSS dataset but only data from selected countries, universities, and subjects of study. First, guided by the availability of secondary data and the relative cultural and institutional similarity, we focus our analysis on the following Western- and Central-European countries: Austria, France, Germany, Hungary, Luxembourg, the Netherlands, and Switzerland. Second, in order 
to avoid a sample selection bias, we only include those universities in the analysis where a simple random sample could be accomplished, i.e. where all students could be contacted by email. Response rates in general online-surveys are rather low and continue to shrink (Dillman et al., 2009). To reduce the risk of a non-response bias we only include universities where the response rate was above $4 \%$ and where 50 or more students filled in the questionnaire. Third, we only consider people up to the age of 40 years studying on the Bachelor, Master or PhD-level; i.e. no Post-docs or faculty members. Finally, we only look at business and economics students. Academic disciplines have their own cultures that transcend organizational and - to a large extent - also national boundaries (Becher, 1994). Because academic subjects differ they are likely to attract students with different skills and career plans (K. Feldman \& Newcomb, 1969). We only select business and economics students because of conceptual and statistical reasons: First, students of these subjects are relatively prone to starting a business and have one of the highest rates of entrepreneurial activity of all subjects (see figure 1). Second, the number of universities in our sample which offer these subjects is large, allowing for a multilevel analysis. Kreft (1996) and Hox (2010) respectively suggest a minimum of about 30 units at each level for being able to conduct robust and reliable multilevel analyses. For business and economics students, we are able to meet this requirement, albeit only narrowly in the case of the number of regions. For other subject groups, the number or observations and, accordingly, also the number of universities and regions is considerably smaller. Thus, we refrain from doing a similar analysis for students from other subject groups like computer science / IT or engineering. Applying these selection criteria gives us a sample of 6,723 respondents at 41 universities in 27 regions $^{3}$.

Overall, the response rate for the 41 universities in our sample is $7.9 \%$ which is comparable to other online-surveys among students (Porter \& Whitcomb, 2003). Still, the rather low response rate raises the question of representativeness. We controlled for a non-response bias using the following

\footnotetext{
${ }^{3}$ The following 41 universities are included in the analysis (sorted by country): Austria: FH Salzburg; France: ESCP Paris; Euromed Marseille; Groupe ESC Troyes; Germany: Hochschule Aalen; Univ. Bayreuth; FH Coburg; Univ. Düsseldorf; Hochschule Esslingen; Zeppelin Univ. Friedrichshafen; Univ. Göttingen; FH Hannover; Univ. Hannover; Hochschule Konstanz; FH Ludwigshafen; Univ. Siegen; Univ. Witten/Herdecke; Westsächsische Hochschule Zwickau; Hungary: EJF - Eötvös József Foiskola (Eötvös József College); ME Miskolci Egyetem (University of Miskolc); SZE - Széchenyi István Egyetem (Szechenyi Istvan University); Luxembourg: Univ. du Luxembourg; Netherlands: Erasmus Univ. Rotterdam; Hogeschool Utrecht; Hotelschool Den Haag; Nyenrode Business University; Rijksuniv. Groningen; Univ. Twente; Univ. Utrecht; FH Campus Wien; Switzerland: Ecole hôtelière de Lausanne; Haute école d'Ingénieurs et de Gestion du Canton de Vaud; Haute école de gestion Arc; Haute école de gestion de Fribourg; Haute école de gestion de Genève; HES-SO MScBA Lausanne; Univ. Bern; Univ. St. Gallen; Univ. de Fribourg; Univ. de Lausanne; Zürcher Hochschule für Angewandte Wissenschaften.
} 
procedure: for every participating university we divide the respondents into three groups (early, middle, late respondents) according to the time when they filled in the questionnaire. We compare early and late respondents using t-tests for equality of means. Under the assumption that non-respondents are more similar to late-respondents than to early-respondents, significant differences between early and late respondents can be interpreted as an indicator for a non-response bias (Oppenheim, 1966). We find no statistically significant differences concerning age, nascent entrepreneurial activity, the individual perception of the entrepreneurial climate at the university, and entrepreneurial background of their parents (variables defined below) $)^{4}$. Overall, we are fairly confident that our sample is representative for the population of business and economics students at the 41 investigated universities.

\subsection{Dependent variables}

Consistent with our conceptual framework we investigate different dependent variables in our analysis: Our first dependent variable is nascent entrepreneurial activity, coded as a binary variable. We consider those people as 'nascent entrepreneurs' who state that they have "made an explicit decision to found a company", "have a concrete time plan when to do the different steps for founding", or "have already started with the realization". Additionally, to qualify as a nascent entrepreneur, people must have conducted at least one of the following gestation activities: formulated a business plan, looked for potential partners, purchased equipment, worked on product development, or asked financial institutions for funding. Thus, we only take into account concrete rather than cognitive behaviours, as demanded by Bird and Schjoedt (2009). Overall, 6.8\% of all business and economics students in our sample count as nascent entrepreneurs. ${ }^{5}$

Our other main dependent variable captures whether students are running a new business. We count those people as 'new entrepreneurs' who state that they are self-employed in a firm founded by

\footnotetext{
${ }^{4}$ We do find a small but statistically significant difference between the two groups for gender (females: early: 43.6\%; late: $47.7 \%$ ). However, our interpretation of this finding is as follows: male students spend more time per day using the internet (Kleimann, Özkilic, \& Göcks, 2008) and are, thus, more likely to be early rather than late respondents in an online survey.

${ }^{5}$ Åstebro et al. (2012) estimate that $6.4 \%$ of all graduates of U.S. universities start a business within three years after graduation. For Germany, this share is about 5.5\% (Holtkamp \& Imsande, 2001). Thus, our estimate of the prevalence of nascent entrepreneurs appears reasonably high.
} 
themselves and who have made their first sales less than 3.5 years ago. ${ }^{6}$ We only consider those students as new entrepreneurs who have started their firm (measured in terms of first sales) while studying. Thus, we exclude any entrepreneurial activity that has been started before entering university because otherwise it would not be possible to check for university influences. Overall, 1.6\% of all business and economics students in our sample count as new entrepreneurs.

Figure 1 presents an overview of these two types of entrepreneurial activities by subject group. While we are able to calculate the prevalence rates of nascent and new entrepreneurs for all subject groups, our following empirical analysis only considers business and economics students, as outlined above.

\section{---- include Figure 1 here ----}

For both, nascent and new entrepreneurs, we furthermore distinguish between ventures based on university internal and external venture ideas. This distinction is based on a question in the GUESSS questionnaire on where the idea for the business came from, which has been adapted from the PSED II questionnaire (Reynolds \& Curtin, 2008). We count all business ideas from 'university studies' or from 'academic, scientific or applied research' as ideas from within the university and those from other sources (e.g. 'current or former work activity', 'hobby or recreational pastime') as external ideas. Overall, $41 \%$ of all nascent and $26 \%$ of all new entrepreneurs are involved in businesses which are - at least partly - based on ideas from the university (figure 2). Thus, overall we have six dependent variables which are all coded as binary variables: (1) nascent and (2) new entrepreneurial activity, and for each (a) overall, (b) based on business ideas from within the university and (c) based on business ideas from other sources outside the university. Figure 2 shows the prevalence rates of the different types of entrepreneurial activity for business and economics students.

$$
\text { ---- include Figure } 2 \text { here ---- }
$$

\subsection{Independent variables}

\footnotetext{
${ }^{6}$ The value of 3.5 years has been selected because it is widely used to distinguish owner-managers of new businesses from those of established businesses, e.g. in many studies based on Global Entrepreneurship Monitor data.

${ }^{7}$ The respondents had to answer the following question: „Where did the idea for this business come from?” Multiple answers were possible.
} 
On the level of the university department, we measure the entrepreneurship course participation rate. In the GUESSS questionnaire, people were asked to indicate whether different types of entrepreneurship courses are offered at their university and whether they have attended. Students who indicate that they have attended at least one course, lecture or seminar on 'Entrepreneurship in general', 'Financing entrepreneurial ventures', 'Technology entrepreneurship', 'Social entrepreneurship', 'Entrepreneurial marketing', 'Innovation and idea generation', or 'Business planning' count as having attended an entrepreneurship-related course. For every university in our sample, we calculate the share of business and economics students who have attended at least one of these courses.

On the regional level, we use the logarithm of GDP/capita (PPP) for 2011 from Cambridge Econometrics' European regional database (NUTS 2 level) where the EU-27 average has been set to 100. This measure has frequently been used in studies on regional entrepreneurship to capture regional economic prosperity (Bosma \& Sternberg, 2014; Hundt, 2012).

\subsection{Control variables: rationale for their inclusion and measurement}

We include age, gender, level of study (i.e. postgraduate student or not), duration of study at the current university, entrepreneurial learning and parental self-employment as control variables on the individual level. Studies usually find an inverse u-shaped relationship between age and start-up activity (see e.g. Wagner \& Sternberg, 2004). As we only investigate students up to 40 years of age, we assume a linear relationship between age and entrepreneurial activity. Women do significantly less often start a firm than men (Minniti \& Naudé, 2010). There are also significant gender differences in the perceptions and attitudes of university students towards entrepreneurship (Sánchez-Escobedo, Díaz-Casero, HernándezMogollón, \& Postigo-Jiménez, 2011). We include duration of study at the current university as control variable because it is likely to impact in how far the organizational context has an effect on students' entrepreneurial propensity. Entrepreneurship education has been found to have a positive, significant relationship with entrepreneurial intentions and with starting a firm (Martin et al., 2013). We control for this effect as follows: On the individual level, we measure formal learning about entrepreneurship by using a 5-item scale proposed by Souitaris et al. (2007). The scale was slightly adapted to capture learning about entrepreneurship from attended university courses in general rather than from one specific course. This measure captures human capital assets (as outcomes of education) rather than human capital 
investments (Martin et al., 2013). People had to answer on a 7-point Likert scale (1=strongly disagree, $7=$ strongly agree), e.g. 'The University offerings I attended increased my understanding of the actions someone has to take in order to start a business ${ }^{8}$. Cronbach's Alpha of this five-item scale is .83 . The variable parental self-employment captures whether peoples' mother or father are or have been selfemployed.

We also control for the following organizational characteristics: Whether it is a university instead of a university of applied sciences; whether it is a private university; and the size of the university, measured in terms of the logarithm of the total number of students. These data were taken from the Eumida dataset (European Commission, 2010). On the regional-level, we control for the average compensation per employee in Euro (ln). Data stems from the Cambridge Econometrics' European regional database (NUTS 2 level) and refers to the year 2011.

The mean values and correlations of all variables used in the analysis are displayed in Table 1.

---- Insert Table 1 here ----

\subsection{Methods}

We calculate binary logistic multi-level regressions in which nascent and new entrepreneurial activities act as dependent variables. This is expedient for two reasons: First, the data covers a large number of individuals as well as broad range of universities and regions and, thus, fulfils an important precondition for reliable multi-level analyses (Raudenbush, Bryk, Cheong, Congdon, \& du Toit, 2004; Raudenbush \& Bryk, 2002). Second, unlike aggregated data, the micro data of GUESSS captures the hierarchical relationship between the individual student and the organizational and regional environment that he or she belongs to, which helps to minimize the risk of ecological fallacies (Robinson, 1950). Compared to ordinary regression modelling, using multi-level analyses provides a number of advantages, two of which are relevant in terms of testing our hypotheses. First, it can be ascertained whether the context levels, i.e. the organizational and regional environment, prove to be statistically relevant in addition to the individual level and therefore may be regarded as autonomous dimensions in explaining nascent

\footnotetext{
${ }^{8}$ The exact wording of these items can be found in Bergmann (2015).
} 
entrepreneurship activities. Second, simultaneously estimating predictor effects from different hierarchical levels makes it possible to quantify the relative impact of each level with respect to the overall hierarchical system (Nezlek, 2011; Rabe-Hesketh \& Skrondal, 2008; Snijders \& Bosker, 2004).

In order to check the necessity of multi-level modelling, we first calculate the intra-class correlation coefficient $\rho$ for the individual, the university, and the regional level. The values of $\rho$ can range from 0 to 1 and express the variance ratio of one level to the sum of all three levels. Consequently, if 1 $>\rho>0$ is valid for all three levels, then the variance of the response variable is linked to the micro as well as to the context units and a multi-level analysis instead of an ordinary single-level regression has to be applied. The starting point of our multi-level analysis is, thus, the null model shown in equation (1), which contains only the error terms $\left(\mathrm{e}_{\mathrm{ijk}}, \mathrm{u}_{\mathrm{jk}}, \mathrm{r}_{\mathrm{k}}\right)$ and the intercept $\delta^{000}$, i.e., the probability of entrepreneurial activity regarding all individuals, and is, therefore, the most frugal of all model variants of the multi-level analysis (Raudenbush \& Bryk, 2002).

$\ln \left[\mathrm{P}\left(\mathrm{Y}_{\mathrm{ijk}}=1\right) / 1-\mathrm{P}\left(\mathrm{Y}_{\mathrm{ijk}}=1\right)\right]=\delta^{000}+\mathrm{e}_{\mathrm{ijk}}+\mathrm{u}_{\mathrm{jk}}{ }^{0}+\mathrm{r}_{\mathrm{k}}^{00}$

With:

$\ln \left[P\left(Y_{i j k}=1\right) / 1-P\left(Y_{i j k}=1\right)\right]:$ Likelihood ratio of being involved in an entrepreneurial activity (ln);

$\delta^{000}:$ Regression intercept;

$e_{i j k}, u_{j k}{ }^{0}, r_{k}^{00}:$ Error terms of the individual (e), university $(u)$, and regional level ( $r$ ).

Basic structure of the three-level model. The structure of our three-level model is strictly hierarchical in the sense that $i$ individuals are nested in $j$ universities, which in turn are nested in $k$ regions. A basic formal notation of the full model is given in equation (2).

$\ln \left[\mathrm{P}\left(\mathrm{Y}_{\mathrm{ijk}}=1\right) / 1-\mathrm{P}\left(\mathrm{Y}_{\mathrm{ijk}}=1\right)\right]=\left[\delta^{000}+\delta^{100} \mathrm{X}_{\mathrm{ijk}}+\delta^{010} \mathrm{U}_{\mathrm{jk}}+\delta^{001} \mathrm{R}_{\mathrm{k}}\right]+\left[\mathrm{e}_{\mathrm{ijk}}+\mathrm{u}_{\mathrm{jk}}{ }^{0}+\mathrm{r}_{\mathrm{k}}{ }^{00}\right]$

With:

$\ln \left[P\left(Y_{i j k}=1\right) / 1-P\left(Y_{i j k}=1\right)\right]:$ Likelihood ratio of being involved in an entrepreneurial activity (ln);

$\delta^{000}:$ Regression intercept;

$X_{i j k}$ : Explanatory variables at the individual level;

$U_{j k}, R_{k}$ : Explanatory variables at the university $(U)$ and the regional level $(R)$;

$e_{i j k}, u_{j k}{ }^{0}, r_{k}^{00}$ : Error terms of the individual (e), university $(u)$, and regional level (r).

Our response variable at the individual level is defined as the logarithmic likelihood ratio of being involved in a nascent or new entrepreneurial activity. Thus, we calculate binary-logistic regressions. As suggested by Hox (2010), we apply a bottom-up strategy consisting of two consecutive analytical steps for each dependent variable. We only include the effects of the bottom level, i.e. of the individual characteristics (X), in the first step, before we add the context factors from the university (U) 
and the regional level $(\mathrm{R})$ in the second step. The fundamental importance of the two context levels is demonstrated by declining deviance values as the contextual predictors are incorporated in the model (Tables 4 and 5).

Cross-sectional studies are prone to a common method bias that might lead to spurious findings. In our case, this risk can be considered small because we mainly use factual information which is combined with aggregate data on the university and the region.

\section{Results}

A descriptive analysis of our data suggests that business and economics students have a high propensity to engage in entrepreneurial activity (see figure 1). Compared to students from other subject groups, they have the highest prevalence rate of nascent entrepreneurs and an above average rate of new entrepreneurs. ${ }^{9}$

We analyse determinants of start-up activities of business and economics students using multilevel-techniques. In a first step we calculate the null models (i.e. excluding all predictors) which allows to investigate which percentage of the overall variance can be attributed to the individual, university, and regional level. For both, nascent entrepreneurs and new entrepreneurs, the largest share of variance can be found on the individual level (Table 2). For nascent entrepreneurs, only $7.3 \%$ of the variance can be attributed to the organizational and regional context while this share is slightly higher for new entrepreneurial activity (11.6\%). There is another important difference between the two groups: For nascent entrepreneurs, the university is a relevant context dimension (6.5\%) while there is hardly any variance on the regional level $(0.8 \%)$. The situation for new entrepreneurs is the other way around.

Overall, there is considerably more variance on the university level for nascent entrepreneurs (6.5\%) compared to new entrepreneurs (3.5\%). Thus, we can support hypothesis 1 that for students the organizational context is more important for nascent entrepreneurship than for the establishment of a new firm.

We also find support for hypothesis 2 . While there is a sizeable variance on the regional level for new entrepreneurs $(8.1 \%)$ there is hardly any for nascent entrepreneurs $(0.8 \%)$. This context level is

\footnotetext{
${ }^{9}$ Because of our survey design, we are not able to make any claims about the representativeness of these findings.
} 
not even statistically significant for nascent entrepreneurs in our model. Overall, the regional context and the context in general are more important for new entrepreneurs compared to nascent entrepreneurs. ---- Insert Table 2 here ----

In a next step we investigate what variables explain the observed variance at the different levels. Table 3 and 4 show the results of the three-level binary-logistic regression models concerning the determinants of nascent and new entrepreneurial activity. As explained above, we calculate two different models for each of the six dependent variables. We find a significant positive effect of the entrepreneurship course participation rate on nascent entrepreneurial activity (all) but no significant effect on new entrepreneurs (all). Thus, we can support hypothesis 3 that the prevalence of fellow students who have attended entrepreneurship education has a positive effect on nascent entrepreneurship of students. It is important to point out that we find this relation while controlling for entrepreneurial learning resulting from attended university offerings on the individual level. Thus, we interpret the effect of the entrepreneurship course participation rate as peer-group effect, as discussed in the following chapter.

We only find weak support for hypothesis 4 . Regional economic prosperity has no significant effect on new entrepreneurs (all) and does not affect any type of nascent entrepreneurship. There is only a significant positive effect for one type of entrepreneurial activity: new entrepreneurs based on ideas from within the university.

There are also some interesting results concerning our control variables. On the individual level, age, being male, and parental self-employment have a consistent and significant positive impact on nascent and new entrepreneurial activity. Entrepreneurial learning has a significant positive effect on nascent entrepreneurs but not on new entrepreneurs. In contrast to that, the duration of study at the current university affects new but not nascent entrepreneurial activity. As control variable on the organizational level, the number of students (ln) has a significant negative effect on nascent entrepreneurial activity (all). On the regional level, compensation per employee has a significant negative effect on some types of entrepreneurial activity.

---- Insert Table 3 and Table 4 here ----

Overall, we find support for hypothesis 1, 2, and 3, and partial support for hypothesis 4 . 


\section{Discussion}

Students' entrepreneurial activities can be attributed to influences on different levels. The observation that the largest share of variance is on the individual level suggests that peoples' individual characteristics are the main determinant of entrepreneurial activities. Variables like age, gender, and parental selfemployment consistently explain a substantial proportion of student entrepreneurship, both nascent and new entrepreneurial activity, and independent from the source of the venture idea. This result stresses the common observation that people - and not regional or organizational characteristics - start new businesses (Reynolds, 2005). While this result might not come as a surprise, it still helps to assess the importance of contextual factors for student entrepreneurship at European universities.

Contextual influences on the organizational and, partly, on the regional level also play a - albeit smaller - role in explaining student start-ups. In other words, entrepreneurial activities of students can be considered as a multi-level phenomenon and should be modelled accordingly, as previously demanded by, for example, Shepherd (2011) and Davidsson et al. (2011).

For nascent entrepreneurship, there is some variance on the university level which cannot solely be explained by peoples' individual characteristics. The respective share is smaller for new entrepreneurs (see Table 2). Thus, while taking first action towards setting up a business seems to depend on university characteristics, the emergence of a new operating firm does so only to a little degree. Correspondingly, the university related variables in our multilevel analysis have an impact on nascent entrepreneurial activity while we do not find an influence of any of these variables on new firm formation. The same pattern of results can also be found for entrepreneurial learning, measured on the individual level. While it has a consistent and highly significant positive influence on nascent entrepreneurship, there is none for new entrepreneurship. Entrepreneurial learning is an individual level variable but it clearly has an organizational dimension because what students learn about entrepreneurship depends on the offerings of the respective university. Overall, these results suggests that university measures to foster students' entrepreneurial activity have an impact on first venture formation efforts, which might develop into operating firms after graduation in the future, but do not have such an effect immediately. Arguably, this result questions the effectiveness of entrepreneurship offerings, which seem to have motivated students to become entrepreneurially active without being able to develop their venture to an operational firm, at least not while studying. There are several explanations for this finding. Presumably, the time frame between the initiation of first gestation activities and the establishment of a new firm is 
too long to be successfully completed while studying. Also, students might lack the necessary professional experience and market knowledge and postpone their entrepreneurial ambitions to a later point in time. Empirical studies usually find university graduates to be more likely to enter self-employment after having gained industry experience rather than directly after graduation (BfS, 2013; Wennberg et al., 2011). Industry experience seems to be even more valuable for entrepreneurial performance than academic knowledge (Wennberg et al., 2011). Last but not least, some of the business ideas of nascent entrepreneurs might on closer inspection simply be not well elaborated and be abandoned sooner or later. Still, fostering nascent entrepreneurship among university students might have a positive effect in the long run. Having gained first entrepreneurial experience while studying might increase the ability to perceive a viable business idea and start a new business at a later point in one's career. In this respect, the university context might still have an impact on actual new businesses. Clearly, this is an avenue for future research, requiring a longitudinal research approach.

The significance of the entrepreneurship course participation rate on nascent entrepreneurship stresses the importance of the social context for the effectiveness of organizational measures. Offering entrepreneurship courses does not only affect the participants themselves but also other students from the same faculty, presumably resulting from social interactions and observations of ones' peers. This finding is similar to results on such peer-effects in other contexts (Bercovitz \& Feldman, 2008; Falck et al., 2012; Nanda \& Sørensen, 2010; Stuart \& Ding, 2006). This is an important results because it suggest that factors like the localised social capital (Kwon et al., 2013) or the climate for entrepreneurship (Rentsch, 1990) mediate the relationship between organizational measures and individual behaviour. Again, we encourage future studies to investigate these mediation effects in more detail and identify the mechanisms at work. As frequently discussed characteristics of entrepreneurial universities (Bercovitz \& Feldman, 2008; Etzkowitz et al., 2000; Geissler et al., 2010; Rasmussen \& Borch, 2010), a fruitful way forward might be to analyse the determinants and effects of a positive entrepreneurial climate or culture among students.

The importance of the regional context increases over the entrepreneurial process which is consistent with previous findings on this issue (Davidsson \& Honig, 2003; Hundt, 2012). Regional economic prosperity, which has been found to be an important driver of a region's start-up activity in general (Reynolds et al., 1994), does not seem to affect students' propensity to take first action for starting a business, i.e. to become a nascent entrepreneur. While this might be interpreted as good news for some 
universities, the probability to progress towards an operating business depends on the regional context, at least for venture ideas from inside the university. Thus, a prosperous regional environment has a positive effect on the establishment of new businesses exploiting ideas from inside the university but no effect on businesses exploiting external ideas. This finding appears counterintuitive at first glance. However, it should be interpreted in relation to the presumptive characteristics of the underlying venture idea. While start-ups based on ideas from study and research are likely to be more innovative, they might also be idea- rather than demand-driven, leading to greater difficulties to establish them in the market (Samuelsson \& Davidsson, 2009). They might be applicable to specific markets only and are, thus, more easily established in prosperous and populous regions that profit from a diverse demand and both types of the aforementioned agglomeration economies, especially urbanization economies. This interpretation supports previous propositions that the entrepreneurial absorptive capacity (Qian \& Acs, 2013) or knowledge capacity (Audretsch \& Lehmann, 2005) of regions is important for successful university knowledge spill-overs. On the other hand, venture ideas from outside the university are to a greater extent market-driven by the perception of an unmet, but not necessarily local or regional demand. Thus, their realization does not depend on the regional environment. It might also be that university external ideas are being developed by students from other regions who are only loosely connected to their university. Because continental European universities typically do not charge significant tuition fees, there is a minority of students who study on a part-time basis while living and working somewhere else. Thus, this finding might be different in other national contexts.

In brief, our result suggests that the university context affects nascent entrepreneurship while the regional context is to some extent important for the actual establishment of a new firm.

\section{Implications for government and university policies}

While individual characteristics are the main driver of students' entrepreneurial behaviour, our results still suggest that universities are able to influence students' entrepreneurial activity to some degree. First, student entrepreneurial activity seems less dependent on regional characteristics than entrepreneurial activities in general, where usually a strong demand-side influence is present (Reynolds et al., 1994). Nascent entrepreneurship and a large share of new business activity of students are not dependent on the regional context. Thus, independent from its location, universities can foster students' first steps 
towards becoming an entrepreneur by offering entrepreneurship courses and motivating students to attend. Geissler et al. (2010) and Hesse (2015) provide some further guidance of what types of university support measures are important. While previous literature has looked at the individual effect of entrepreneurship education (Martin et al., 2013; Souitaris et al., 2007), our results stress the organizational dimension because such courses do not only affect the participants but have a broader peer-effect on other students, as well.

However, some reservations concerning the possible room for manoeuvre of universities also apply. Our analysis reveals that new ventures based on ideas from within the university are more easily established in economically growing regions where agglomeration economies in general and urbanization economies in particular are present, putting some universities in an unfavourable position. Still, case studies suggest that universities outside core regions can also develop capabilities to successfully promote spin-offs (Rasmussen \& Borch, 2010). Positive role models of entrepreneurial students may have a stronger effect in such non-core regions as there is a lack of entrepreneurial role models outside the university (Lafuente, Vaillant, \& Rialp, 2007).

One might also argue that university programmes to support entrepreneurship among students are more effective when coordinated with respective strategies of the region the university is located in. As many regional governments have developed entrepreneurship support policies themselves (very often not explicitly addressing the local universities), a coordinated strategy of both parties - government and university - may be more successful than isolated efforts. Regional governments should view local universities as an important part of the regional entrepreneurial eco-system, while universities should acknowledge the crucial role of the regional environment as an important driver of their students' entrepreneurial activities.

\section{Limitations and recommendations for future research}

No empirical study can ever claim to be perfect. First, we include only a small number of variables on the university level in our analysis because the collection of comparable data on European universities is still in its infancy and hardly any secondary data are available (Daraio et al., 2011). It was beyond the scope of this study to gather additional comparable data on organizational characteristics of universities in seven different countries. Secondly, we find a partial relationship between the entrepreneurship course 
participation rate and students' entrepreneurial activity which we assume to be the effect of observing and exchanging ideas with entrepreneurially active peers. However, as Manski (1993) has pointed out, there are three different possible explanations for the relationship between group characteristics and the behaviour of individuals who are part of this group. While we assume that our observed relationship is the result of a contextual influence it might also be due to an endogenous effect or a correlated effect because of certain unobserved characteristics or self-selection. Yet, we argue that the latter is unlikely to be important in our case: Prior research suggests that students at European universities are unlikely to self-select into universities with a more or less positive entrepreneurial climate because other factors are important for students' decision where to study (Heine et al., 2008). Third, while our study can contribute to our understanding of student entrepreneurship, we have not been able to collect data on university graduates. The large number of nascent compared to new entrepreneurs suggests that a substantial number of new businesses might be started after graduation, as documented by Åstebro et al. (2012) for three universities in Sweden and the U.S.. Thus, the overall effect of the organizational and regional context on students' entrepreneurship might only become visible once people graduate from university and try to establish their business. Finally, we are not able to control for the quality of new ventures. It might be that a supportive university context fosters the development of high-quality startups which are, however, very small in number.

\section{Conclusion}

We follow calls of Shepherd (2011), Davidsson et al. (2011), and others to investigate entrepreneurial decision making in a multilevel perspective. Our paper contributes to a better understanding of student entrepreneurship and the relative importance of the organizational and the regional context. Our analysis suggests that different context levels are important at different stages of the venture creation process and for different types of venture ideas. University influences may encourage first action for starting a business but do not seem to lead to the establishment of new firms, at least not while people are studying. For students, the actual establishment of new firms is more strongly influenced by the regional than the organizational context. Our results also highlight the importance of viewing student entrepreneurship as a socially embedded process where organizational measures like entrepreneurship course offerings do not only affect course participants but have a broader impact as well. 


\section{Bibliography}

Abreu, M., \& Grinevich, V. (2013). The nature of academic entrepreneurship in the UK: Widening the focus on entrepreneurial activities. Research Policy, 42(2), 408-422. doi:10.1016/j.respol.2012.10.005

Acs, Z. J., Bosma, N., \& Sternberg, R. (2011). Entrepreneurship in world cities. In M. Minniti (Ed.), The Dynamics of Entrepreneurship: Theory and Evidence. Oxford University. Oxford University: Oxford University Press.

Aldrich, H. E., \& Cliff, J. E. (2003). The pervasive effects of family on entrepreneurship: toward a family embeddedness perspective. Journal of Business Venturing, 18(5), 573-596. doi:10.1016/S08839026(03)00011-9

Andersson, M., \& Koster, S. (2011). Sources of persistence in regional start-up rates-evidence from Sweden. Journal of Economic Geography, 11 (February 2010), 179-201. doi:10.1093/jeg/lbp069

Åstebro, T., Bazzazian, N., \& Braguinsky, S. (2012). Startups by recent university graduates and their faculty: Implications for university entrepreneurship policy. Research Policy, 41(4), 663-677. doi:10.1016/j.respol.2012.01.004

Audretsch, D. B. (2014). From the entrepreneurial university to the university for the entrepreneurial society. The Journal of Technology Transfer, 39(3), 313-321. doi:10.1007/s10961-012-9288-1

Audretsch, D. B., \& Fritsch, M. (1994). The Geography of Firm Births in Germany. Regional Studies, 28(4), 359-365. doi:10.1080/00343409412331348326

Audretsch, D. B., \& Keilbach, M. (2004). Entrepreneurship Capital and Economic Performance. Regional Studies, 38(8), 949-959. doi:10.1080/0034340042000280956

Audretsch, D. B., \& Lehmann, E. E. (2005). Does the Knowledge Spillover Theory of Entrepreneurship hold for regions? Research Policy, 34(8), 1191-1202. doi:10.1016/j.respol.2005.03.012

Autio, E., Kenney, M., Mustar, P., Siegel, D. S., \& Wright, M. (2014). Entrepreneurial innovation: The importance of context. Research Policy, 43(7), 1097-1108. doi:10.1016/j.respol.2014.01.015

Backes-Gellner, U., Demirer, G., \& Sternberg, R. (2002). Individuelle und regionale Einflussfaktoren auf die Gründungsneigung von Hochschülern. In J. Schmude \& J. Leiner (Eds.), Unternehmensgründungen. Interdisziplinäre Beiträge zum Entrepreneurship Research (pp. 63-96). Heidelberg: Physica.

Bandura, A. (1971). Social Learning Theory. New York: General Learning Press.

Beaudry, C., \& Schiffauerova, A. (2009). Who's right, Marshall or Jacobs? The localization versus urbanization debate. Research Policy, 38(2), 318-337. doi:10.1016/j.respol.2008.11.010

Becher, T. (1994). The Significance of Disciplinary Differences. Studies in Higher Education, 19(2), 151-161.

Bercovitz, J., \& Feldman, M. (2008). Academic Entrepreneurs: Organizational Change at the Individual Level. Organization Science, 19(1), 69-89. doi:10.1287/orsc.1070.0295

Bergmann, H. (2015). The formation of opportunity beliefs among university entrepreneurs: an empirical study of research- and non-research-driven venture ideas. The Journal of Technology Transfer, online. doi:10.1007/s10961-015-9458-z

BfS. (2013). Selbstständige Erwerbstätigkeit bei Hochschulabsolventinnen und -absolventen. Neuchâtel: Bundesamt fuer Statistik (Swiss Federal Statistical Office).

Bhave, M. (1994). A process model of entrepreneurial venture creation. Journal of Business Venturing, 9(3), 223-242. doi:10.1016/0883-9026(94)90031-0

Bird, B., \& Schjoedt, L. (2009). Entrepreneurial Behavior: Its Nature, Scope, Recent Research, and Agenda for Future Research. In A. L. Carsrud \& M. Brännback (Eds.), Understanding the Entrepreneurial Mind (pp. 327-358). New York, NY: Springer. doi:10.1007/978-1-4419-0443-0

Boschma, R. (2005). Proximity and Innovation: A Critical Assessment. Regional Studies, 39(1), 61-74. doi:10.1080/0034340052000320887

Bosma, N., \& Schutjens, V. (2011). Understanding regional variation in entrepreneurial activity and entrepreneurial attitude in Europe. The Annals of Regional Science, 47(3), 711-742. doi:10.1007/s00168010-0375-7

Bosma, N., \& Sternberg, R. (2014). Entrepreneurship as an Urban Event? Empirical Evidence from European 
Cities. Regional Studies, 48(6), 1016-1033. doi:10.1080/00343404.2014.904041

Brixy, U., Sternberg, R., \& Stüber, H. (2012). The Selectiveness of the Entrepreneurial Process. Journal of Small Business Management, 50(1), 105-131.

Carter, N. M., Gartner, W. B., \& Reynolds, P. D. (1996). Exploring start-up event sequences. Journal of Business Venturing, 11(3), 151-166. doi:10.1016/0883-9026(95)00129-8

Casper, S. (2013). The spill-over theory reversed: The impact of regional economies on the commercialization of university science. Research Policy. doi:10.1016/j.respol.2013.04.005

Dahl, M. S., \& Sorenson, O. (2012). Home Sweet Home: Entrepreneurs' Location Choices and the Performance of Their Ventures. Management Science, 58(6), 1059-1071. doi:10.1287/mnsc.1110.1476

Daraio, C., Bonaccorsi, A., Geuna, A., Lepori, B., Bach, L., Bogetoft, P., ... Eeckaut, P. Vanden. (2011). The European university landscape: A micro characterization based on evidence from the Aquameth project. Research Policy, 40(1), 148-164. doi:10.1016/j.respol.2010.10.009

Davidsson, P. (2003). The domain of entrepreneurship research: Some Suggestions. In J. Katz \& D. A. Shepherd (Eds.), Cognitive approaches. Advances in entrepreneurship. Firm emergence and growth (Vol. 6, pp. 315-372). Oxford: Elsevier/JAI Press.

Davidsson, P. (2015). Entrepreneurial opportunities and the entrepreneurship nexus: A re-conceptualization. Journal of Business Venturing, 30(5), 674-695. doi:10.1016/j.jbusvent.2015.01.002

Davidsson, P., Gordon, S. R., \& Bergmann, H. (2011). Introduction. In P. Davidsson, S. R. Gordon, \& H. Bergmann (Eds.), Nascent Entrepreneurship (pp. xiii-xxxvi). Cheltenham: Edward Elgar.

Davidsson, P., \& Honig, B. (2003). The role of social and human capital among nascent entrepreneurs. Journal of Business Venturing, 18(3), 301-331. doi:10.1016/S0883-9026(02)00097-6

Dillman, D. A., Smyth, J. D., \& Christian, L. M. (2009). Internet, Mail, and Mixed-Mode Surveys: The Tailored Design Method (3rd ed.). Hoboken, NJ: Wiley.

Djokovic, D., \& Souitaris, V. (2008). Spinouts from academic institutions: a literature review with suggestions for further research. The Journal of Technology Transfer, 33(3), 225-247. doi:10.1007/s10961-006-9000-4

Drakopoulou Dodd, S., \& Hynes, B. C. (2012). The impact of regional entrepreneurial contexts upon enterprise education. Entrepreneurship \& Regional Development, 24(9-10), 741-766. doi:10.1080/08985626.2011.566376

Eickelpasch, A., \& Fritsch, M. (2005). Contests for cooperation-A new approach in German innovation policy. Research Policy, 34(8), 1269-1282. doi:10.1016/j.respol.2005.02.009

Etzkowitz, H. A., \& Leydesdorff, L. (Eds.). (1997). Universities and the Global Knowledge Economy: A Triple Helix of Academic-Industry-Government Relations. London: Cassell Academic.

Etzkowitz, H. A., \& Leydesdorff, L. (2000). The dynamics of innovation: from National Systems and "Mode 2" to a Triple Helix of university-industry-government relations. Research Policy, 29(2), 109-123. doi:10.1016/S0048-7333(99)00055-4

Etzkowitz, H. A., Webster, A., Gebhardt, C., \& Terra, B. R. C. (2000). The future of the university and the university of the future: evolution of ivory tower to entrepreneurial paradigm. Research Policy, 29(2), 313-330. doi:10.1016/S0048-7333(99)00069-4

European Commission. (2010). Feasibility Study for Creating a European University Data Collection. Final Study Report. Brussels.

European Commission. (2012). Effects and impact of entrepreneurship programmes in higher education. Brussels.

Falck, O., Heblich, S., \& Luedemann, E. (2012). Identity and entrepreneurship: do school peers shape entrepreneurial intentions? Small Business Economics, 39(1), 39-59. doi:10.1007/s11187-010-9292-5

Feldman, K., \& Newcomb, T. (1969). The Impact of College on Students. San Francisco: Jossey-Bass.

Feldman, M. (2001). The Entrepreneurial Event Revisited: Firm Formation in a Regional Context. Industrial and Corporate Change, 10(4), 861-891.

Geissler, M. (2013). Determinanten des Vorgründungsprozesses. Wiesbaden: Springer Fachmedien Wiesbaden. 
doi:10.1007/978-3-658-01665-4

Geissler, M., Jahn, S., \& Haefner, P. (2010). The entrepreneurial climate at universities: the impact of organizational factors. In D. Smallbone, J. Leitao, M. Raposo, \& F. Welter (Eds.), The Theory and Practice of Entrepreneurship (pp. 12-31). Cheltenham, UK / Northampton, MA: Edward Elgar Publishing.

Heine, C., Willich, J., Schneider, H., \& Sommer, D. (2008). Studienanfänger im Wintersemester 2007/08: Wege zum Studium, Studien- und Hochschulwahl, Situtaion bei Studienbeginn. Hannover.

Hesse, N. (2015). Career paths of academic entrepreneurs and university spin-off growth. In R. Baptista \& J. Leitão (Eds.), Entrepreneurship, Human Capital, and Regional Development (pp. 29-57). Heidelberg: Springer.

Holtkamp, R., \& Imsande, J. (2001). Selbständigkeit von Hochschulabsolventen - Entwicklungen, Situation und Potential. Hannover: HIS Hochschul-Informations-System.

Hoppe, M. (2015). Policy and entrepreneurship education. Small Business Economics, (August). doi:10.1007/s11187-015-9676-7

Houser, C. (2014). Why the University Is the Ideal Startup Platform. Wired.com. Retrieved from http://www.wired.com/2014/02/university-ideal-startup-platform/

Hox, J. (2010). Multilevel Analysis: Techniques and Applications (2nd ed.). New York: Routledge.

Hundt, C. (2012). Zur Erklärung von Gründungsaktivitäten - Eine Mehrebenenanalyse aus individueller, regionaler und nationaler Perspektive. Reihe ,,Wirtschaftsgeographie“, Bd. 54. Münster: LIT-Verlag.

Hundt, C., \& Sternberg, R. (2014). Explaining new firm creation in Europe from a spatial and time perspective: A multilevel analysis based upon data of individuals, regions and countries. Papers in Regional Science. doi:10.1111/pirs.12133

Johns, G. (2006). The essential impact of context on organizational behavior. Academy of Management Review, 31(2), 386-408. doi:10.5465/AMR.2006.20208687

Kleimann, B., Özkilic, M., \& Göcks, M. (2008). Studieren im Web 2.0. Hannover. Retrieved from https://hisbus.his.de/hisbus/docs/hisbus21.pdf

Kuratko, D. F. (2005). The Emergence of Entrepreneurship Education: Development, Trends, and Challenges. Entrepreneurship Theory and Practice, 29(5), 577-597.

Kwon, S., Heflin, C., \& Ruef, M. (2013). Community Social Capital and Entrepreneurship. American Sociological Review, 78(6), 980-1008. doi:10.1080/15575330.2014.880495

Lafuente, E., Vaillant, Y., \& Rialp, J. (2007). Regional Differences in the Influence of Role Models: Comparing the Entrepreneurial Process of Rural Catalonia. Regional Studies, 41(6), 779-796. doi:10.1080/00343400601120247

Laspita, S., Breugst, N., Heblich, S., \& Patzelt, H. (2012). Intergenerational transmission of entrepreneurial intentions. Journal of Business Venturing, 27(4), 414-435. doi:10.1016/j.jbusvent.2011.11.006

Lawton Smith, H., \& Bagchi-Sen, S. (2012). The research university, entrepreneurship and regional development: Research propositions and current evidence. Entrepreneurship \& Regional Development, 24(5-6), 383-404. doi:10.1080/08985626.2011.592547

Manski, C. F. (1993). Identification of Endogenous Social Effects: The Reflection Problem. Review of Economic Studies, 60, 531-542.

Martin, B. C., McNally, J. J., \& Kay, M. J. (2013). Examining the formation of human capital in entrepreneurship: A meta-analysis of entrepreneurship education outcomes. Journal of Business Venturing, 28(2), 211-224. doi:10.1016/j.jbusvent.2012.03.002

Michelacci, C., \& Silva, O. (2007). Why So Many Local Entrepreneurs? The Review of Economics and Statistics, 89(November), 615-633. doi:10.1162/rest.89.4.615

Minniti, M., \& Naudé, W. (2010). What do we know about the patterns and determinants of female entrepreneurship across Countries? European Journal of Development Research, 22(3), 277-293.

Mosey, S., \& Wright, M. (2007). From Human Capital to Social Capital: A Longitudinal Study of TechnologyBased Academic Entrepreneurs. Entrepreneurship Theory and Practice, 31(6), 909-935. 
doi:10.1111/j.1540-6520.2007.00203.x

Nanda, R., \& Sørensen, J. B. (2010). Workplace Peers and Entrepreneurship. Management Science, 56(7), 11161126. doi: $10.1287 / \mathrm{mnsc} .1100 .1179$

Nezlek, J. B. (2011). Multilevel Modelling for Social and Personality Psychology. London: Sage.

Oppenheim, A. N. (1966). Questionnaire Design and Attitude Measurement. London: Heinemann.

Pittaway, L., \& Cope, J. (2007). Entrepreneurship Education: A Systematic Review of the Evidence. International Small Business Journal, 25(5), 479-510. doi:10.1177/0266242607080656

Porter, S. R., \& Whitcomb, M. E. (2003). The Impact of Lottery Incentives on Student Survey Response Rates. Research in Higher Education, 44(4), 389-407.

Qian, H., \& Acs, Z. J. (2013). An absorptive capacity theory of knowledge spillover entrepreneurship. Small Business Economics, 40(2), 185-197. doi:10.1007/s11187-011-9368-x

Rabe-Hesketh, S., \& Skrondal, A. (2008). Multilevel and Longitudinal Modeling using Stata (2nd ed.). College Station, TX: Stata Press.

Rasmussen, E., \& Borch, O. J. (2010). University capabilities in facilitating entrepreneurship: A longitudinal study of spin-off ventures at mid-range universities. Research Policy, 39(5), 602-612.

doi:10.1016/j.respol.2010.02.002

Rasmussen, E., Mosey, S., \& Wright, M. (2011). The Evolution of Entrepreneurial Competencies: A Longitudinal Study of University Spin-Off Venture Emergence. Journal of Management Studies, 48(6), 1314-1345. doi:10.1111/j.1467-6486.2010.00995.x

Raudenbush, S. W., \& Bryk, A. (2002). Hierarchical Linear Models: Applications and Data Analyses Methods (2nd ed.). Newbury Park, CA: Sage Publications.

Raudenbush, S. W., Bryk, A., Cheong, Y. F., Congdon, R., \& du Toit, M. (2004). HLM 6: Hierarchical Linear and Nonlinear Modelling. Lincolnwood, IL: SSI Scientific Software International.

Rentsch, J. R. (1990). Climate and culture: Interaction and qualitative differences in organizational meanings. Journal of Applied Psychology, 75(6), 668-681. doi:10.1037//0021-9010.75.6.668

Reynolds, P. D. (2005). Understanding Business Creation: Serendipity and Scope in Two Decades of Business Creation Studies. Small Business Economics, 24(4), 359-364. doi:10.1007/s11187-005-0692-X

Reynolds, P. D., Carter, N. M., Gartner, W. B., \& Greene, P. G. (2004). The prevalence of nascent entrepreneurs in the United States: Evidence from the Panel Study of Entrepreneurial Dynamics. Small Business Economics, 23(4), 263-284. doi:10.1023/B:SBEJ.0000032046.59790.45

Reynolds, P. D., \& Curtin, R. T. (2008). Business Creation in the United States: Panel Study of Entrepreneurial Dynamics II Initial Assessment. Foundations and Trends in Entrepreneurship, 4(3), 155-307. doi:10.1561/0300000022

Reynolds, P. D., Miller, B., \& Maki, W. R. (1995). Explaining Regional Variation in Business Births and Deaths: U.S. 1976-88. Small Business Economics, 7(5), 389-407. doi:10.1007/BF01302739

Reynolds, P. D., Storey, D., \& Westhead, P. (1994). Cross-national Comparisons of the Variation in New Firm Formation Rates. Regional Studies, 28(4), 443-456.

Robinson, W. (1950). Ecological Correlations and Behaviour of Individuals. American Sociological Review, 15, 351-357.

Rosenthal, S. S., \& Strange, W. C. (2004). Evidence on the nature and sources of agglomeration economies. Handbook of Regional and Urban Economics, 4(04), 2120-2167. doi:10.1016/S0169-7218(04)07049-2

Samuelsson, M., \& Davidsson, P. (2009). Does venture opportunity variation matter? Investigating systematic process differences between innovative and imitative new ventures. Small Business Economics, 33(2), 229-255. doi:10.1007/s11187-007-9093-7

Sánchez-Escobedo, M. D. L. C., Díaz-Casero, J. C., Hernández-Mogollón, R., \& Postigo-Jiménez, M. V. (2011). Perceptions and attitudes towards entrepreneurship. An analysis of gender among university students. International Entrepreneurship and Management Journal, 7(4), 443-463. doi:10.1007/s11365-011-0200-5

Shane, S. (2003). A General Theory of Entrepreneurship: The Individual-Opportunity Nexus. Cheltenham, UK / 
Northampton, MA: Edward Elgar Publishing.

Shepherd, D. A. (2011). Multilevel Entrepreneurship Research: Opportunities for Studying Entrepreneurial Decision Making. Journal of Management, 37(2), 412-420. doi:10.1177/0149206310369940

Shepherd, D. A., McMullen, J. S., \& Jennings, P. D. (2007). The formation of opportunity beliefs: overcoming ignorance and reducing doubt. Strategic Entrepreneurship Journal, 1(1-2), 75-95. doi:10.1002/sej.3

Siegel, D. S., \& Wright, M. (2015). Academic Entrepreneurship: Time for a Rethink? British Journal of Management, 26, n/a-n/a. doi:10.1111/1467-8551.12116

Sieger, P., Fueglistaller, U., \& Zellweger, T. (2011). Entrepreneurial Intentions and Activities of Students across the World. International Report of the GUESSS Project 2011. St. Gallen.

Snijders, T., \& Bosker, R. (2004). Multilevel Analysis: An Introduction to Basic and Advanced Multi-level Modeling (5th ed.). London et al.: Sage.

Souitaris, V., Zerbinati, S., \& Al-Laham, A. (2007). Do entrepreneurship programmes raise entrepreneurial intention of science and engineering students? The effect of learning, inspiration and resources. Journal of Business Venturing, 22(4), 566-591. doi:10.1016/j.jbusvent.2006.05.002

Stam, E. (2009). Why Butterflies Don`t Leave: Locational Behavior of Entrepreneurial Firms. Economic Geography, 83(1), 27-50. doi:10.1111/j.1944-8287.2007.tb00332.x

Sternberg, R. (2009). Regional Dimensions of Entrepreneurship. Foundations and Trends in Entrepreneurship, 5(4), 211-340. doi:10.1561/0300000024

Sternberg, R., \& Wagner, J. (2005). Zur Evidenz regionaler Determinanten im Kontext individueller Grundungsaktivitaten. Empirische Befunde aus dem Regionalen Entrepreneurship Monitor (REM). Zeitschrift Für Wirtschaftsgeographie, 49(3/4), 167.

Stuart, T. E., \& Ding, W. W. (2006). When Do Scientists Become Entrepreneurs ? The Social Structural Antecedents of. American Journal of Sociology, 112(1), 97-144.

Stuetzer, M., Obschonka, M., Brixy, U., Sternberg, R., \& Cantner, U. (2014). Regional characteristics, opportunity perception and entrepreneurial activities. Small Business Economics, 42(2), 221-244. doi:10.1007/s11187-013-9488-6

Van Looy, B., Landoni, P., Callaert, J., van Pottelsberghe, B., Sapsalis, E., \& Debackere, K. (2011). Entrepreneurial effectiveness of European universities: An empirical assessment of antecedents and tradeoffs. Research Policy, 40(4), 553-564. doi:10.1016/j.respol.2011.02.001

Vohora, A., Wright, M., \& Lockett, A. (2004). Critical junctures in the development of university high-tech spinout companies. Research Policy, 33(1), 147-175.

Wagner, J., \& Sternberg, R. (2004). Start-up activities, individual characteristics, and the regional milieu: Lessons for entrepreneurship support policies from German micro data. The Annals of Regional Science, 38(2), 219-240. doi:10.1007/s00168-004-0193-x

Walter, S. G., Parboteeah, K. P., \& Walter, A. (2013). University departments and self-employment intentions of business students: A cross-level analysis. Entrepreneurship Theory and Practice, 37(2), 175-200. doi:10.1111/j.1540-6520.2011.00460.x

Welter, F. (2011). Contextualizing Entrepreneurship-Conceptual Challenges and Ways Forward. Entrepreneurship Theory and Practice, 35(1), 165-184. doi:10.1111/j.1540-6520.2010.00427.x

Wennberg, K., Wiklund, J., \& Wright, M. (2011). The effectiveness of university knowledge spillovers: Performance differences between university spinoffs and corporate spinoffs. Research Policy, 40(8), 1128-1143. doi:10.1016/j.respol.2011.05.014

Wood, M. S., McKelvie, A., \& Haynie, J. M. (2014). Making it personal: Opportunity individuation and the shaping of opportunity beliefs. Journal of Business Venturing, 29(2), 252-272. doi:10.1016/j.jbusvent.2013.02.001

Zellweger, T., Sieger, P., \& Halter, F. (2011). Should I stay or should I go? Career choice intentions of students with family business background. Journal of Business Venturing, 26(5), 521-536.

doi:10.1016/j.jbusvent.2010.04.001 
Table 1: Mean values and correlations of dependent and independent variables

\begin{tabular}{|c|c|c|c|c|c|c|c|c|c|c|c|c|c|c|c|}
\hline & & \multicolumn{6}{|l|}{ Mean } & \multicolumn{8}{|c|}{ Pearson correlation } \\
\hline & & & (1) & (2) & (3) & (4) & (5) & (6) & (7) & (8) & (9) & (10) & (11) & (12) & (13) \\
\hline (1) & Nascent (All) & 0.068 & & & & & & & & & & & & & \\
\hline (2) & New Entrepreneur (All) & 0.016 & & & & & & & & & & & & & \\
\hline (3) & Gender $=$ male & 0.54 & $0.11^{* *}$ & $0.07 * *$ & & & & & & & & & & & \\
\hline (4) & Age (years) & 23.79 & $0.06^{* *}$ & $0.05^{* *}$ & $0.10^{* *}$ & & & & & & & & & & \\
\hline (5) & Parental self-employment (1=yes) & 0.42 & $0.08^{* *}$ & $0.06^{* *}$ & -0.01 & $-0.03 *$ & & & & & & & & & \\
\hline (6) & Postgraduate student (1=yes) & 0.29 & 0.02 & $0.05^{* *}$ & $0.06 * *$ & $0.38^{* *}$ & 0.00 & & & & & & & & \\
\hline (7) & Entrepreneurial learning (index) & 4.50 & $0.08^{* *}$ & $0.04 * *$ & $0.04 * *$ & $-0.05^{* *}$ & $0.06^{* *}$ & $-0.03^{*}$ & & & & & & & \\
\hline (8) & Duration of study at current univ. & 2.46 & 0.01 & $0.06^{* *}$ & $0.06^{* *}$ & $0.33^{* *}$ & -0.02 & $0.28 * *$ & $-0.05^{* *}$ & & & & & & \\
\hline (9) & Entrepreneurship course participation rate & 0.66 & $0.06^{* *}$ & 0.02 & $-0.08^{* *}$ & $-0.12^{* *}$ & $0.09^{* *}$ & -0.01 & $0.22 * *$ & 0.02 & & & & & \\
\hline (10) & University vs university of applied science ( $1=$ university) & 0.48 & -0.01 & 0.02 & $0.08^{* *}$ & $-0.09 * *$ & $-0.03^{*}$ & $0.29 * *$ & $-0.07 * *$ & $0.06^{* *}$ & $-0.06^{* *}$ & & & & \\
\hline (11) & Private vs public university (1=private) & 0.10 & $0.04 * *$ & -0.02 & -0.01 & 0.00 & $0.08^{* *}$ & $-0.04 * *$ & $0.19^{* *}$ & $0.03 *$ & $0.20 * *$ & $-0.19 * *$ & & & \\
\hline (12) & Number of students (ln) & 7.93 & $-0.05 * *$ & $0.05^{* *}$ & $0.06^{* *}$ & $-0.07 * *$ & $-0.05 * *$ & $0.07 * *$ & $-0.17 * *$ & $0.10^{* *}$ & $-0.11^{* *}$ & $0.41 * *$ & $-0.43 * *$ & & \\
\hline (13) & GDP per capita (ln) & 4.77 & -0.01 & 0.02 & $0.14 * *$ & $-0.03 *$ & 0.01 & 0.00 & -0.02 & $-0.04 * *$ & $-0.31^{* *}$ & $-0.15^{* *}$ & $0.14^{* *}$ & $0.12 * *$ & \\
\hline (14) & Compensation per employee (ln) & 10.47 & 0.00 & 0.00 & $0.15^{* *}$ & $-0.03 *$ & $0.06^{* *}$ & 0.01 & $0.09^{* *}$ & $-0.05 * *$ & $-0.13^{* *}$ & $-0.20 * *$ & $0.21 * *$ & $-0.21 * *$ & $0.71^{* *}$ \\
\hline
\end{tabular}

**. Correlation is significant at the 0.01 level (2-tailed). *. Correlation is significant at the 0.05 level (2-tailed).

Note: The analysis is based on data from 6,723 business and economics students at 41 universities; own calculation based on GUESSS data. 
Figure 1: Prevalence rates of nascent and new entrepreneurs by subject group

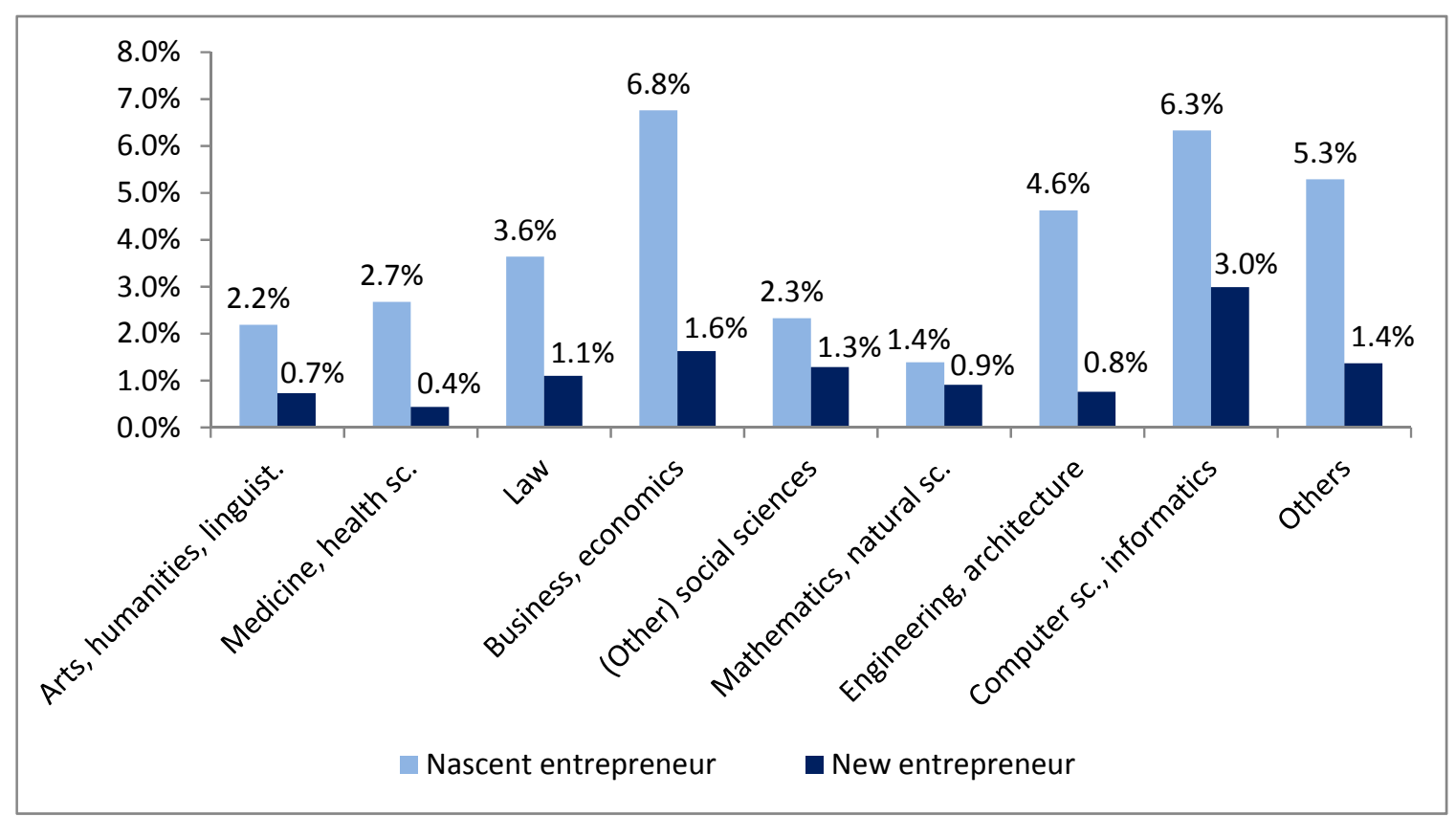

Note: The analysis is based on data from 26,623 students at 61 universities. In the subsequent multilevel analysis we use the subsample of business and economics students. 
Figure 2: Rates of nascent and new entrepreneurs by source of venture idea

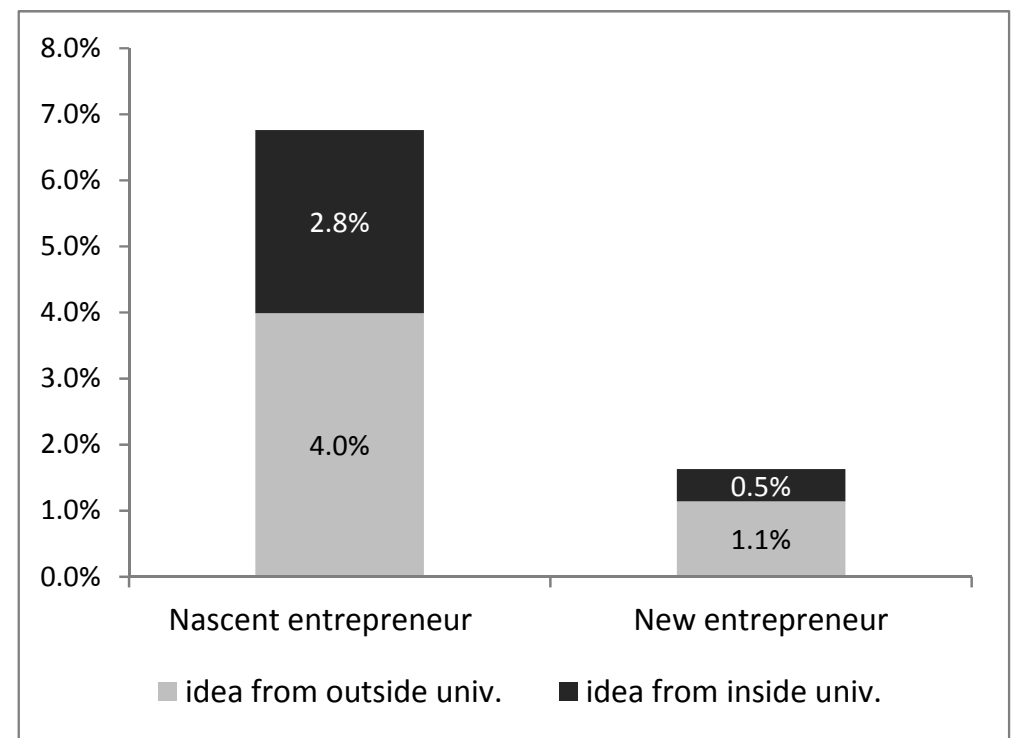

Note: The analysis is based on data from 6,723 business and economics students at 41 universities; own calculation based on GUESSS data. 
Table 2: Proportion of variance at different levels: Nascent entrepreneurs and new entrepreneurs

\begin{tabular}{|c|c|c|}
\hline & Nascent Entrepreneur & New Entrepreneur \\
\hline $\begin{array}{l}\text { Individual level Residual variance } \sigma^{2} \mathrm{e} \\
\text { Intra-class correlation coefficient / Variance ratio } \rho_{\mathrm{e}} \\
\sigma^{2} \mathrm{e} /\left(\sigma^{2} \mathrm{e}+\sigma^{2} \mathrm{u}+\sigma^{2} \mathrm{r}\right) * 100\end{array}$ & $\begin{array}{l}3.29 * * \\
92.7 \%\end{array}$ & $\begin{array}{l}3.29 * * \\
\mathbf{8 8 . 4} \%\end{array}$ \\
\hline $\begin{array}{l}\text { University level Residual variance } \sigma^{2} u \\
\text { Intra-class correlation coefficient / Variance ratio } \rho_{u} \\
\sigma^{2} u /\left(\sigma^{2} e+\sigma^{2} u+\sigma^{2} r\right) * 100\end{array}$ & $\begin{array}{l}0.23 * * \\
6.5 \%\end{array}$ & $\begin{array}{l}0.13^{*} \\
3.5 \%\end{array}$ \\
\hline $\begin{array}{l}\text { Regional level } \quad \text { Residual variance } \sigma^{2} \mathrm{r} \\
\text { Intra-class correlation coefficient / Variance ratio } \rho_{\mathrm{r}} \\
\sigma^{2} \mathrm{r} /\left(\sigma^{2} \mathrm{e}+\sigma^{2} \mathrm{u}+\sigma^{2} \mathrm{r}\right) * 100\end{array}$ & 0.03 & $0.30^{*}$ \\
\hline
\end{tabular}

Influence is significant on the $0.01(* *)$ or the $0.05\left(^{*}\right)$ level.

The analy ses are based on data from 6453 (model 1) and 6127 (model 2) individuals from 41 universities in 27 regions.

Source: Own calculations based on GUESSS data. 


\section{Table 3: Results of multilevel binary-logistic regression models: Nascent entrepreneurs}

\begin{tabular}{|c|c|c|c|c|c|c|c|c|c|c|c|c|}
\hline \multirow{5}{*}{$\begin{array}{l}\text { Reference group: Non-entrepreneurs (0) } \\
\text { Regression intercept }\end{array}$} & & & & & & & & & & & & \\
\hline & \multicolumn{12}{|c|}{ Nascent Entrepreneurs } \\
\hline & \multicolumn{4}{|c|}{ All } & \multicolumn{4}{|c|}{ Idea from inside the university } & \multicolumn{4}{|c|}{ Idea from outside the university } \\
\hline & \multicolumn{2}{|c|}{ Individual } & \multicolumn{2}{|c|}{ Individual and context } & \multicolumn{2}{|c|}{ Individual } & \multicolumn{2}{|c|}{ Individual and context } & \multicolumn{2}{|c|}{ Individual } & \multicolumn{2}{|c|}{ Individual and context } \\
\hline & $\begin{array}{c}\text { Coeff. } \\
(-) 2.715^{* *}\end{array}$ & $\begin{array}{l}\text { (s.e.) } \\
(0.08) \\
\end{array}$ & $\begin{array}{c}\text { Coeff. } \\
(-) 2.704^{* *}\end{array}$ & $\begin{array}{l}\text { (s.e.) } \\
(0.08) \\
\end{array}$ & $\begin{array}{c}\text { Coeff. } \\
(-) 3.582 * *\end{array}$ & $\begin{array}{l}\text { (s.e.) } \\
(0.10) \\
\end{array}$ & $\begin{array}{c}\text { Coeff. } \\
(-) 3.546^{* *}\end{array}$ & $\begin{array}{l}\text { (s.e.) } \\
(0.11)\end{array}$ & $\begin{array}{c}\text { Coeff. } \\
(-) 3.294 * *\end{array}$ & $\begin{array}{l}\text { (s.e.) } \\
(0.09)\end{array}$ & $\begin{array}{c}\text { Coeff. } \\
(-) 3.336^{* *}\end{array}$ & $\begin{array}{l}\text { (s.e.) } \\
(0.10) \\
\end{array}$ \\
\hline R: GDP per capita (ln) & & & (+) 0.227 & $(\mathbf{0 . 1 5})$ & & & $(+) 0.331$ & (0.19) & & & $(+) 0.124$ & $(\mathbf{0 . 2 1})$ \\
\hline $\mathrm{R}^{\mathrm{C}}$ : Compensation per employee (ln) & & & $(-) 0.227$ & $(0.12)$ & & & (-) $0.423^{*}$ & $(0.18)$ & & & (-) 0.096 & $(0.14)$ \\
\hline U: Entrepreneurship course participation rate & & & $(+) 0.264 *$ & (0.11) & & & $(+) 0.141$ & $(\mathbf{0 . 1 0 )}$ & & & $(+)$ 0.355* & (0.12) \\
\hline $\mathrm{U}^{\mathrm{C}}$ : University vs university of applied science ( $1=$ university) & & & $(+) 0.125$ & $(0.10)$ & & & $(+) 0.091$ & $(0.10)$ & & & $(+) 0.111$ & $(0.12)$ \\
\hline $\mathrm{U}^{\mathrm{C}}$ : Private vs public university $(1=$ private $)$ & & & (-) 0.022 & $(0.08)$ & & & (+) 0.106 & $(0.11)$ & & & (-) 0.120 & $(0.09)$ \\
\hline $\mathrm{U}^{\mathrm{C}}$ : Number of students (ln) & & & (-) $0.289^{*}$ & $(0.11)$ & & & (-) 0.235 & $(0.16)$ & & & (-) 0.247 & $(0.14)$ \\
\hline $\mathrm{X}^{1}$ : Gender $(1=$ male $)$ & $(+) 0.489 * *$ & $(0.05)$ & $(+) 0.499 * *$ & $(0.06)$ & $(+) 0.561 * *$ & $(0.08)$ & $(+) 0.576^{* *}$ & $(0.09)$ & $(+) 0.435^{* *}$ & $(0.07)$ & $(+) 0.452 * *$ & $(0.07)$ \\
\hline $\mathrm{X}^{2}$ : Age (years) & $(+) 0.193 * *$ & $(0.05)$ & (+) $0.202 * *$ & $(0.05)$ & $(+) 0.147 * *$ & $(0.04)$ & (+) $0.145^{* *}$ & $(0.05)$ & (+) $0.212^{* *}$ & $(0.07)$ & $(+) 0.228^{* *}$ & $(0.07)$ \\
\hline $\mathrm{X}^{3}$ : Family business background $(1=$ yes $)$ & $(+) 0.311 * *$ & $(0.05)$ & $(+) 0.306^{* *}$ & $(0.06)$ & $(+) 0.258^{* *}$ & $(0.06)$ & (+) $0.256^{* *}$ & $(0.07)$ & (+) $0.346^{* *}$ & $(0.06)$ & (+) $0.337^{* *}$ & $(0.07)$ \\
\hline $\mathrm{X}^{4}:$ Academic status $(1=$ post-grad $)$ & (+) 0.029 & $(0.06)$ & (+) 0.012 & $(0.06)$ & $(+) 0.121$ & $(0.07)$ & (+) 0.107 & $(0.08)$ & (-) 0.033 & $(0.07)$ & (-) 0.054 & $(0.08)$ \\
\hline $\mathrm{X}^{5}$ : Entrepreneurial learning (index) & $(+) 0.275^{* *}$ & $(0.06)$ & $(+) 0.250^{* *}$ & $(0.06)$ & $(+) 0.320^{* *}$ & $(0.10)$ & $(+) 0.289^{* *}$ & $(0.10)$ & $(+) 0.261 * *$ & $(0.06)$ & $(+) 0.231 * *$ & $(0.06)$ \\
\hline $\mathrm{X}^{6}:$ Duration of study at current university (years) & (-) 0.035 & $(0.05)$ & (-) 0.028 & $(0.05)$ & (-) 0.060 & $(0.07)$ & (-) 0.049 & $(0.08)$ & (-) 0.017 & $(0.07)$ & (-) 0.013 & $(0.07)$ \\
\hline University level variance component: var $\left(\mathrm{u}_{\mathrm{jk}}{ }^{0}\right)$ & \multicolumn{2}{|c|}{$0.182 * *$} & \multicolumn{2}{|c|}{$0.106 * *$} & \multicolumn{2}{|c|}{0.224} & \multicolumn{2}{|c|}{$0.110^{* *}$} & \multicolumn{2}{|c|}{$0.160^{*}$} & \multicolumn{2}{|c|}{$0.041 *$} \\
\hline Regional level variance component: $\operatorname{var}\left(\mathrm{r}_{\mathrm{k}}{ }^{00}\right)$ & \multicolumn{2}{|c|}{0.017} & \multicolumn{2}{|l|}{0.001} & \multicolumn{2}{|c|}{0.058} & 0.036 & & \multicolumn{2}{|l|}{0.001} & \multicolumn{2}{|l|}{0.007} \\
\hline Deviance - null model & \multirow{3}{*}{\multicolumn{2}{|c|}{$\begin{array}{c}15405.24 \\
15067.43 * *\end{array}$}} & \multirow{3}{*}{\multicolumn{2}{|c|}{$\begin{array}{c}15067.43 \\
15050.48^{* *}\end{array}$}} & \multirow{3}{*}{\multicolumn{2}{|c|}{$\begin{array}{c}13292.38 \\
13066.66^{* *}\end{array}$}} & \multirow{3}{*}{\multicolumn{2}{|c|}{$\begin{array}{c}13066.66 \\
13054.12^{*}\end{array}$}} & \multirow{3}{*}{\multicolumn{2}{|c|}{$\begin{array}{c}13991.03 \\
13731.01^{* *}\end{array}$}} & \multirow{3}{*}{\multicolumn{2}{|c|}{$\begin{array}{c}13731.01 \\
13712.94^{* *}\end{array}$}} \\
\hline Deviance - individual model & & & & & & & & & & & & \\
\hline Deviance - individual and context model & & & & & & & & & & & & \\
\hline
\end{tabular}

The table displays standardized logit coefficients and corresponding standard errors. Influence is significant on the $0.01\left(^{* *}\right)$ or $0.05\left(^{*}\right)$ level respectively.

Please note that all predictor variables are grand mean centered.
The analyses are based on data from 6,453 individuals from 41 universities in 27 regions.

Sources: Own calculations based on data from GUESSS and Cambridge Econometrics' Database. 


\section{Table 4: Results of multilevel binary-logistic regression models: New entrepreneurs}

\begin{tabular}{|c|c|c|c|c|c|c|c|c|c|c|c|c|}
\hline \multirow{4}{*}{$\begin{array}{l}\text { Reference group: Non-entrepreneurs (0) } \\
\text { Regression intercept }\end{array}$} & \multicolumn{12}{|c|}{ New Entrepreneurs } \\
\hline & \multicolumn{4}{|c|}{ All } & \multicolumn{4}{|c|}{ Idea from inside the university } & \multicolumn{4}{|c|}{ Idea from outside the university } \\
\hline & \multicolumn{2}{|c|}{ Individual } & \multicolumn{2}{|c|}{ Individual and context } & \multicolumn{2}{|c|}{ Individual } & \multicolumn{2}{|c|}{ Individual and context } & \multicolumn{2}{|c|}{ Individual } & \multicolumn{2}{|c|}{ Individual and contex } \\
\hline & $\begin{array}{c}\text { Coeff. } \\
\text { (-) } 4.456^{* *}\end{array}$ & \begin{tabular}{|l|}
$($ (s.e. $)$ \\
$(0.15)$
\end{tabular} & \begin{tabular}{|c|} 
Coeff. \\
(-) $4.594 * *$
\end{tabular} & \begin{tabular}{|l|} 
(s.e. $)$ \\
$(0.20)$
\end{tabular} & \begin{tabular}{|c|} 
Coeff. \\
(-) $5.613^{* *}$
\end{tabular} & $\begin{array}{l}\text { (s.e.) } \\
(0.21)\end{array}$ & $\begin{array}{c}\text { Coeff. } \\
(-) 5.942 * *\end{array}$ & $\begin{array}{l}\text { (s.e.) } \\
(0.29)\end{array}$ & $\begin{array}{c}\text { Coeff. } \\
(-) 4880 * *\end{array}$ & $\left|\begin{array}{l|}\text { (s.e. }) \\
(0.18)\end{array}\right|$ & $\mid \begin{array}{c}\text { Coeff. } \\
(-) 5.018^{* *}\end{array}$ & $\begin{array}{l}\text { (s.e.) } \\
(0.26)\end{array}$ \\
\hline R: GDP per capita (ln) & & & (+) 0.655 & $(\mathbf{0 . 3 4})$ & & & $(+) 0.883^{*}$ & $(0.39)$ & & & $(+) 0.536$ & $(0.32)$ \\
\hline $\mathrm{R}^{\mathrm{C}}$ : Compensation per employee $(\mathrm{ln})$ & & & (-) 0.485 & $(0.29)$ & & & (-) 0.227 & $(0.38)$ & & & $(-) 0.495^{*}$ & $(0.23)$ \\
\hline U: Entrepreneurship course participation rate & & & $(+) 0.278$ & $(\mathbf{0 . 1 5 )}$ & & & $(+) 0.102$ & $(0.25)$ & & & $(+) 0.344$ & (0.18) \\
\hline $\mathrm{U}^{\mathrm{C}}$ : University vs university of applied science ( $1=$ university) & & & $(+) 0.001$ & $(0.16)$ & & & $(+) 0.218$ & $(0.22)$ & & & (-) 0.087 & $(0.17)$ \\
\hline $\mathrm{U}^{\mathrm{C}}$ : Private vs public university $(1=$ private $)$ & & & (-) 0.186 & $(0.19)$ & & & (-) 0.098 & $(0.23)$ & & & (-) 0.287 & $(0.18)$ \\
\hline $\mathrm{U}^{\mathrm{C}}$ : Number of students (ln) & & & (+) 0.191 & $(0.18)$ & & & $(+) 0.151$ & $(0.26)$ & & & $(+) 0.219$ & $(0.19)$ \\
\hline $\mathrm{X}^{1}$ : Gender $(1=$ male $)$ & $(+) 0.502 * *$ & $(0.07)$ & $(+) 0.526^{* *}$ & $(0.08)$ & $(+) 0.263^{*}$ & $(0.12)$ & (+) 0.229 & $(0.13)$ & $(+) 0.638^{* *}$ & $(0.11)$ & $(+) 0.671 * *$ & $(0.12)$ \\
\hline $\mathrm{X}^{2}$ : Age (years) & $(+) 0.183 * *$ & $(0.06)$ & $(+) 0.196^{* *}$ & $(0.07)$ & $(+) 0.194 * *$ & $(0.07)$ & $(+) 0.229 * *$ & $(0.08)$ & (+) 0.156 & $(0.09)$ & $(+) 0.177^{*}$ & $(0.09)$ \\
\hline $\mathrm{X}^{3}$ : Family business background $(1=$ yes $)$ & $(+) 0.489 * *$ & $(0.07)$ & $(+) 0.500 * *$ & $(0.07)$ & $(+) 0.395 * *$ & $(0.08)$ & $(+) 0.414 * *$ & $(0.09)$ & $(+) 0.527 * *$ & $(0.09)$ & $(+) 0.535 * *$ & $(0.10)$ \\
\hline $\mathrm{X}^{4}:$ Academic status $(1=$ post-grad $)$ & $(+) 0.112$ & $(0.10)$ & $(+) 0.143$ & $(0.12)$ & $(+) 0.282$ & $(0.15)$ & $(+) 0.247$ & $(0.17)$ & $(+) 0.058$ & $(0.12)$ & (+) 0.098 & $(0.13)$ \\
\hline $\mathrm{X}^{5}$ : Entrepreneurial learning (index) & $(+) 0.303$ & $(0.17)$ & (+) 0.327 & $(0.19)$ & $(+) 0.363$ & $(0.24)$ & (+) 0.400 & $(0.25)$ & (+) 0.269 & $(0.18)$ & (+) 0.297 & $(0.20)$ \\
\hline $\mathrm{X}^{6}$ : Duration of study at current university (years) & $(+) 0.262 * *$ & $(0.06)$ & $(+) 0.262 * *$ & $(0.06)$ & $(+) 0.268^{*}$ & $(0.13)$ & $(+) 0.269^{*}$ & $(0.13)$ & $(+) 0.264 * *$ & $(0.09)$ & $(+) 0.253 * *$ & $(0.09)$ \\
\hline University level variance component: $\operatorname{var}\left(\mathrm{u}_{\mathrm{jk}}{ }^{0}\right)$ & \multicolumn{2}{|c|}{$0.235^{+}$} & \multicolumn{2}{|l|}{0.043} & \multicolumn{2}{|l|}{0.184} & \multicolumn{2}{|c|}{0.039} & \multicolumn{2}{|c|}{0.254} & \multicolumn{2}{|c|}{0.001} \\
\hline Regional level variance component: $\operatorname{var}\left(\mathrm{r}_{\mathrm{k}}{ }^{00}\right)$ & \multicolumn{2}{|c|}{0.190} & \multicolumn{2}{|c|}{$0.048^{*}$} & \multicolumn{2}{|l|}{0.137} & \multicolumn{2}{|l|}{0.026} & \multicolumn{2}{|c|}{0.072} & \multicolumn{2}{|l|}{0.080} \\
\hline Deviance - null model & \multirow{3}{*}{\multicolumn{2}{|c|}{$\begin{array}{c}12565.59 \\
12336.92^{* *}\end{array}$}} & \multirow{3}{*}{\multicolumn{2}{|c|}{$\begin{array}{c}12336.92 \\
12324.17^{*}\end{array}$}} & \multirow{3}{*}{\multicolumn{2}{|c|}{$\begin{array}{c}11743.86 \\
11583.14^{* *}\end{array}$}} & \multirow{3}{*}{\multicolumn{2}{|c|}{$\begin{array}{l}11583.14 \\
11576.77\end{array}$}} & \multirow{3}{*}{\multicolumn{2}{|c|}{$\begin{array}{c}12235.17 \\
12024.47 * *\end{array}$}} & \multirow{3}{*}{\multicolumn{2}{|c|}{$\begin{array}{c}12024.47 \\
12013.03 *\end{array}$}} \\
\hline Deviance - individual model & & & & & & & & & & & & \\
\hline Deviance - individual and context model & & & & & & & & & & & & \\
\hline
\end{tabular}

The table displays standardized logit coefficients and corresponding standard errors. Influence is significant on the $0.01(* *)$ or $0.05\left(^{*}\right)$ level respectively.
The analyses are based on data from 6,127 individuals from 41 universities in 27 regions.

Sources: Own calculations based on data from GUESSS and Cambridge Econometrics' Database.

Please note that all predictor variables are grand mean centered. 